\title{
The Prangos genus: a comprehensive review on traditional use, phytochemistry, and pharmacological activities
}

\author{
Javad Mottaghipisheh $\cdot$ Tivadar Kiss $\cdot$ Barbara Tóth $\cdot$ Dezső Csupor $\mathbb{C}$
}
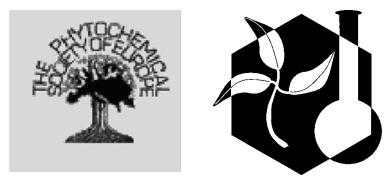

Received: 11 January 2020/ Accepted: 25 May 2020/Published online: 4 June 2020

(C) The Author(s) 2020

\begin{abstract}
The members of the Prangos genus (Apiaceae) have been widely applied in the Iranian traditional medicine internally and externally for different purposes. The aim of this review is to summarize the ethnomedicinal and food applications of Prangos species and to gather the phytochemical and pharmacological data on this genus. Among the 129 constituents isolated from Prangos species, coumarin derivatives are the main compounds. Several papers report the compositions of essential oils obtained from different plant parts, mostly containing monoterpene and sesquiterpene hydrocarbons. Various pharmacological activities of essential oils, crude extracts or isolated compounds of the Prangos species have been observed, primarily in in vitro experiments. Antioxidant, antimicrobial, cytotoxic and anti-proliferative activities have been the most extensively studied. The efficacy and safety of Prangos plants have not been assessed in animal experiments or clinical trials. Although their furocoumarin content might be a source of adverse effects, toxic effects of Prangos species have not been reported. It can be
\end{abstract}

Electronic supplementary material The online version of this article (https://doi.org/10.1007/s11101-020-09688-3) contains supplementary material, which is available to authorized users.

J. Mottaghipisheh · T. Kiss · B. Tóth · D. Csupor ( $₫)$ Department of Pharmacognosy, Faculty of Pharmacy, University of Szeged, Eötvös u. 6, Szeged 6720, Hungary e-mail: csupor.dezso@pharmacognosy.hul concluded, that further preclinical and clinical data are necessary to assess the rationale and safety of the medicinal and food use of Prangos species.

Keywords Coumarins $\cdot$ Ethnobotanical $\cdot$ Functional foods $\cdot$ Pharmacological properties $\cdot$ Prangos
Abbreviations
A2780S Human ovarian carcinoma cell line
A375 Human melanoma cell line
A431 Human epidermoid carcinoma cell line
A549 Human lung cell line
ABTS 2,2'-SzinobisAzino-bis-(3- ethylbenzthiazoline-6-sulfonate)
ACE Angiotensin-converting enzyme
AChE Acetylcholinesterase enzyme
AE Acarbose equivalent
BChE Butyryl-cholinesterase enzyme
BHK 21 Baby hamster kidney fibroblast cell line
Caco-2 Human colon cancer cell line
CCL-221 Human colorectal cancer cell line
COX-1 Cyclooxygenase enzyme type 1
COX-2 Cyclooxygenase enzyme type 2
CUPRAC Cupric ion reducing activity
DEET $\quad N, N$-Diethyl-3-methylbenzamide
DPPH 2,2-Diphenyl-1-picrylhydrazyl
EO Essential oil
FRAP Ferric reducing antioxidant power
GE Galanthamine equivalent
GST Glutathione-S-transferase 
HIV-1 Human immunodeficiency virus type 1

HSV Herpes simplex virus type 1

IL-6 Interleukin 6

IL-8 Interleukin 8

IZ Growth inhibition zone

KAE Kojic acid equivalent

$\mathrm{LC}_{50}$ Concentrations that killed $50 \%$ of the exposed insects

$\mathrm{LC}_{99} \quad$ Concentrations that killed $99 \%$ of the exposed insects

LDH Lactate dehydrogenase

LNCaP Human prostatic cell line

LPO Lipid peroxidation inhibition

MED Minimum effective dose

MIC Minimum inhibitory concentration

MRSA Methicillin-resistant Staphylococcus aureus

NCI- Human lung cell line

$\mathrm{H} 322$

NSAID Non-steroidal anti-inflammatory drug

OE Orlistat equivalent

ORAC Oxygen radical absorbance capacity

PC-3 Human prostate cell line

$\mathrm{PFU} \quad$ Plaque-forming units

$\mathrm{RC}_{50} \quad$ Concentration that reduces $50 \%$ of the free radical concentration

TBA Thiobarbituric acid

$\mathrm{TC}_{50} \quad$ Drug concentration that reduces the cell growth $50 \%$

TE Trolox equivalent

THP1 Human leukemia cell line

TNF- $\alpha$ Tumour necrosis factor alpha

\section{Introduction}

Apiaceae (syn. Umbelliferae) is one of the largest families of Plant Kingdom: it comprises 434 genera and 3780 species. Most of these species are aromatic plants with hollow stems, and several representatives are used as vegetables or condiments (Stevens 2001). The genus Prangos Lindley (syn. Cryptodiscus Fischer \& C. A. Meyer, Koelzella Hiroe; Neocryptodiscus Hedge \& Lamond), distributed from Portugal to Tibet, consists of 45 species (Stevens 2001). The centre of the diversity of Prangos genus is the Irano-Turanian region. The main anatomical and morphological features characteristic to Apiaceae species, can also be discovered in Prangos species with some specific morphological changes regarding fruits, endosperms and mesocarp. According to phylogeny studies, Prangos is a monophyletic taxon closely related to Bilacunaria and Cachrys (Lyskov et al. 2017) genera. Species of Prangos genus have been used in the traditional medicine of the Mediterranean region and the Middle East.

Prangos species possess a great importance as spices and medicinal plants in Asia, especially in Iran, Turkey, and Iraq. The above-ground part, the roots and the essential oil of different species have been applied internally and externally as well. The most popular indications of the plants are the alleviation of different gastrointestinal symptoms, but various other uses have also been reported. In the recent years, the number of papers reporting experimental data on the biological effects of Prangos species have been increased. However, there is no systematic review available that summarizes the current knowledge on these species.

Coumarin derivatives, particularly furocoumarins have been isolated and identified as the predominant secondary metabolites of several Prangos species. Considering the fact that furocoumarins may possess phototoxic and carcinogenic effects (Melough et al. 2018), the assessment of qualitative and quantitative data on the furocoumarin content of these plants is of primary importance. Furthermore, the summary of phytochemical components of the genus may be useful to understand better the described bioactivities and also to provide new directions for further research.

Our aim was to review scientific data on traditional use, bioactivity, and phytochemical profile of the Prangos genus, by searching for the keyword "Prangos" (from 1974 to 2019) on PubMed, and Web of Science databases (last search: 01. 11. 2019).

\section{Traditional use of Prangos species}

The ethnomedicinal applications of the Prangos genus are shown in Table S1. In Turkey, Prangos plants are used as carminative, tonic, and anthelmintic agents, in the treatment of external bleeding, gastric or digestive disorders, wounds, scars, and leuckoplakia. Moreover, Prangos species are also used as stimulants, aphrodisiacs and natural fertilizers (Oke Altuntas et al. 
2016; Ozek et al. 2018). Some species of this genus are consumed as spices or food additives as well.

Due to its aphrodisiac, coagulant, carminative and tonic effects, different Prangos species are part of the traditional medicine (Razavi et al. 2010c; Abolghasemi and Piryaei 2012). The most commonly used species of this genus are $P$. ferulacea and $P$. pabularia. The leaves of these plants are traditionally used as laxative, antihypertensive, and carminative agents and are also recommended for the treatment of digestive disorders (Dokovic et al. 2004; Sagun et al. 2006; Kazerooni et al. 2006; Durmaz et al. 2006; Özek et al. 2007; Ahmed et al. 2011a; Razavi 2012b; Farooq et al. 2014a; Shokoohinia et al. 2014; Namjoyan et al. 2015; Seidi Damyeh et al. 2016; Tabanca et al. 2016; Gheisari et al. 2016; Yousefi et al. 2017; Delnavazi et al. 2017; Kiliç et al. 2017; Ozek et al. 2018; Sadeghi and Bazdar 2018; Abbas-Mohammadi et al. 2018; Numonov et al. 2018). In Western North Iran, the essential oil from roots of $P$. ferulacea has been traditionally used for wound healing (Yousefi et al. 2017).

The fresh fruits and roots of $P$. pabularia are also consumed in Tajikistan (local name: Yugan) for its putative effects in the treatment of vitiligo, and because these are considered to have tonic effects (Numonov et al. 2018). In India, only P. pabularia (local names: Komal, Kurangas) is native. The roots and fruits of this species are used as laxative, liver tonic, diuretic, carminative, and stimulant. Infusion from the roots is used in the treatment of flatulence, indigestion and improving of menstrual cycle in women (Farooq et al. 2014b). In Turkish folk medicine, the roots of $P$. pabularia, and P. meliocarpoides are eaten with honey as aphrodisiac (Ozek et al. 2018).

In Kurdish traditional medicine (eastern part of Iraq), the aerial part of $P$. haussknechtii is used for its carminative, diuretic, and sedative effects (Dissanayake et al. 2017).

Besides their medicinal use, Prangos species are extensively used as food additives, spices and flavouring agents (Table S1). P. ferulacea is used in Iran (Iranian name: Djashir) as yogurt flavouring, and animal fodder (Damyeh et al. 2016; Abbas-Mohammadi et al. 2018, Shokoohinia et al. 2014), whereas in Turkey (local names: Casir, Caksir) it is used as food ingredient, e.g. in Van herby cheese, aroma and flavour component (Sagun et al. 2006; Ozek et al.
2018) and as stimulant tea (Kiliç et al. 2017). The young stems and shoots of $P$. platychlaena Boiss. (local names: Cagsir, Caksir, Kirkor, and Korkor) are eaten freshly and used as pickle in Eastern Turkey, while it is consumed after baking in the central part of the country. Furthermore, the roots of the plant are often powdered and mixed with honey to consume as aphrodisiac (Ozek et al. 2018; Tabanca et al. 2018).

\section{Pharmacological and biological activities}

Bioactivity of extracts, essential oils, and isolated secondary metabolites of Prangos species have been investigated by several research groups. The most extensively studied effect of Prangos species have been experimented in vitro. Among them antioxidant activity is the major bioactivity evaluation. The only in vivo study is evaluation of abortifacient effect of the $P$. ferulacea leaves extracts. Antimicrobial (antibacterial, antifungal, and antiviral), anti-cancer (cytotoxic and antiproliferative), anti-inflammatory, anti-diabetic, neuroprotective and other pharmacological activities of Prangos species have also been assessed. Allelopathic effects including phytotoxic, insecticidal and repellent activities of EOs of Prangos species have also been reported. In the majority of the experiments, aerial parts were used, usually as methanolic or hydroethanolic extracts. The pharmacological studies that had been performed on Prangos spp. are listed in Table S2.

\section{Antioxidant activities}

Free radicals are generally synthesized as by-products in all living organisms and can result in oxidative damage to biological molecules like DNA, fatty acids, and amino acids. Free radicals and oxidative stress are proved to play an essential role in the development of certain chronic diseases (Sarma et al. 2010), hence plants possessing remarkable antioxidant activity may play role in health protection.

Many plant products (EOs, different extracts and pure constituents) obtained from different parts of Prangos species have been evaluated for their free radical scavenging activity, and several of these natural products possessed noteworthy antioxidant potential. Antioxidant tests, including ABTS, CUPRAC, DPPH, FRAP, LPO, ORAC and TBA 
assays were carried out in vitro. Of the tested samples, the methanolic extracts of $P$. ferulacea demonstrated high antioxidant activity in various assays; and among the isolated compounds, the coumarin scopoletin (9) obtained from $P$. uloptera exhibited the most significant activity (Razavi et al. 2008b).

\section{Crude extracts and essential oils}

In a study, various extracts of Prangos species have been subjected to antioxidant activity assays. Aqueous extracts of $P$. denticulata leaf $\left(\mathrm{IC}_{50}: 0.048 \mathrm{mg} / \mathrm{mL}\right)$ and $P$. heyniae fruit $\left(\mathrm{IC}_{50}: 0.119 \mathrm{mg} / \mathrm{mL}\right)$ showed the highest antioxidant activities using the DPPH test compared to $\alpha$-tocopherol ( $\mathrm{IC}_{50}: 0.011 \mathrm{mg} / \mathrm{mL}$ ), BHA $\left(\mathrm{IC}_{50}: 0.003 \mathrm{mg} / \mathrm{mL}\right.$ ), and BHT ( $\mathrm{IC}_{50}: 0.023 \mathrm{mg} / \mathrm{mL}$ ) as controls. In metal chelating assay the aqueous leaf extract of $P$. denticulata $(0.94 \mathrm{mg} / \mathrm{mL})$ and methanol root extract of $P$. heyniae $(0.74 \mathrm{mg} / \mathrm{mL})$ were the most potent extracts. Aqueous extracts from leaves and fruits of $P$. denticulata were the strongest antioxidant agents with inhibition values of $69.93 \%$ and $68.98 \%$, respectively, by using plasma lipid peroxidation method (Oke-Altuntas et al. 2015). In a comparative study, the hot water extract of $P$. denticulata leaf exerted the highest ability in scavenging free radicals $\left(\mathrm{IC}_{50}: 0.048 \mathrm{mg} / \mathrm{mL}\right.$ ), compared to various extracts of the species and the aqueous extract of $P$. platychloena was equally active $\left(\mathrm{IC}_{50}: 0.048 \mathrm{mg} / \mathrm{mL}\right.$ ) (Oke Altuntas et al. 2011).

The antioxidant activities of the EO and the hydroalcoholic extracts (particularly methanolic) of $P$. ferulacea have been extensively studied. The hydroalcoholic extract obtained from $P$. ferulacea flowers possesses the highest antioxidant capacity with $\mathrm{IC}_{50}=8.01 \mu \mathrm{L} / \mathrm{mL}$ in the 2,2-diphenyl-1-picrylhydrazyl (DPPH) assay. The other samples derived from this species were less active: hydroalcoholic extract of flowers $\left(\mathrm{IC}_{50}: 8.01 \pm 0.60 \mu \mathrm{L} / \mathrm{mL}\right)>$ hydroalcoholic extract of leaves $\left(\mathrm{IC}_{50}: 10.99 \mu \mathrm{L} /\right.$ $\mathrm{mL})>$ aqueous extract of flowers $\left(\mathrm{IC}_{50}: 14.59 \mu \mathrm{L} /\right.$ $\mathrm{mL})>$ aqueous extract of leaves $(18.61 \mu \mathrm{L} / \mathrm{mL})>$ EO of leaves $(22.99 \mu \mathrm{L} / \mathrm{mL})>$ EO of flowers $(23.90$ $\mu \mathrm{L} / \mathrm{mL}$ ) (Bazdar et al. 2018). Evaluation of free radical scavenging activity of hydroalcoholic extracts obtained from ten Iranian $P$. ferulacea samples revealed moderate activities with $\mathrm{EC}_{50}$ values of the most potent samples of $0.013 \mathrm{mg} / \mathrm{mL}$ and $10.55 \mathrm{mmol}$ Trolox equivalent (TE)/g in the DPPH and oxygen radical absorbance capacity (ORAC) assays, respectively (Bagherifar et al. 2019). In a similar study, antioxidant activities of methanolic and aqueous extracts obtained from the roots, herbs, and flowers of four Prangos species (P. ferulacea, P. uechtritzii, $P$. heyniae, $P$. meliocarpoides var. meliocarpoides) collected in Turkey were measured by the thiobarbituric acid assay (TBA). Among the tested extracts, the methanolic extract of $P$. ferulacea and $P$. uechtritzii fruits had the highest antioxidant activities with $\mathrm{IC}_{50}$ values of $0.047 \mathrm{mg} / \mathrm{mL}$ and $0.049 \mathrm{mg} / \mathrm{mL}$, respectively (Ahmed et al. 2011b). In a comparative study, radical scavenging and lipid peroxidation inhibitory activities of $P$. ferulacea were compared to other Apiaceae species including Chaerophyllum macropodum Boiss. and Heracleum persicum Desf. The methanolic extract of aerial parts of $P$. ferulacea with $\mathrm{IC}_{50}=0.242$ and $0.152 \mathrm{mg} / \mathrm{mL}$ for DPPH radical scavenging and lipid peroxidation inhibition (LPO), respectively, showed better antioxidant activities in comparison with the two other investigated plants (Çoruh et al. 2007). From P. ferulacea samples, the ethyl acetate extract of the plant had the highest antioxidant activity among the different extracts using the DPPH and the ABTS assays, showing $\mathrm{IC}_{50}$ values of $1.4 \mathrm{mg} / \mathrm{g}$ and $5.4 \mathrm{mg} / \mathrm{g}$, respectively (Dagdelen et al. 2014). $\mathrm{MeOH}$ extract of $P$. ferulacea fruit exerted a good potency in scavenging of free radicals in the DPPH assay, with $6.4 \%$ of inhibition compared with ascorbic acid $(4.0 \%)$ as the positive control at a concentration of $0.01 \mathrm{mg} / \mathrm{mL}$ (Cesur et al. 2017). A methanolic extract of $P$. ferulacea $\left(\mathrm{IC}_{50}: 0.228 \mathrm{mg} /\right.$ $\mathrm{mL}$ ) exhibited moderate antioxidant activity, evaluated by the DPPH method (Mavi et al. 2004).

The antioxidant activity of EO, $n$-hexane, dichloromethane, and methanolic extracts obtained from aerial parts of $P$. gaubae were evaluated in the DPPH, cupric ion reducing activity (CUPRAC) and ferric reducing antioxidant power (FRAP) assays. The methanolic extract was the most active extract using the DPPH (0.47 mmol TEs/g), CUPRAC $(0.89 \mathrm{mmol}$ TEs/g), and FRAP (0.52 mmol TEs/g) assays, whereas the EO had the highest capacity in scavenging of free radicals using the ABTS method (2.02 mmol TEs/g) (Bahadori et al. 2017a).

Yazici et al. (2013) reported that the methanolic extracts of $P$. hulusii aerial parts had stronger antioxidant activity compared to its roots analysed by different assays (Yazici et al. 2013). 
The fruits of $P$. meliocarpoides were extracted with various solvents, and among the extracts the methanolic extract showed the highest DPPH radical scavenging effect $\left(\mathrm{IC}_{50}: 0.088 \mathrm{mg} / \mathrm{mL}\right)$, followed by the aqueous, acetone and ethyl acetate extracts (Oke Altuntas et al. 2016).

The dichloromethane extract of $P$. pabularia roots (collected from Iran) displayed the highest antioxidant activity using the DPPH assay with an $\mathrm{RC}_{50}$ (concentration of the test material that reduces $50 \%$ of the free radical concentration) value of $0.08 \mathrm{mg} / \mathrm{mL}$ followed by the methanolic and $n$-hexane extracts with $\mathrm{RC}_{50} \mathrm{~s}$ of 0.17 and $1.38 \mathrm{mg} / \mathrm{mL}$, respectively (Salehi et al. 2016).

Pure compounds

8-Geranyloxy psoralen (32), a furocoumarin isolated from the roots and fruits of $P$. uloptera exerted weak antioxidant effect with $\mathrm{RC}_{50}$ of $0.262 \mathrm{mg} / \mathrm{mL}$ in the DPPH assay (Razavi et al. 2009a). Scopoletin (9) was the most active antioxidant compound from the five extracted coumarins (xanthotoxin (36), prangenin (73), scopoletin (9), deltoin (79) and prangolarin (syn. oxypeucedanin) (48)) from the aerial parts of $P$. uloptera, with an $\mathrm{RC}_{50}$ value of $0.0243 \mathrm{mg} / \mathrm{mL}$ (Razavi et al. 2008b). The free radical scavenging activity of oxypeucedanin (48), isolated from leaves of P. uloptera was evaluated by the $\mathrm{DPPH}$ assay $\left(\mathrm{RC}_{50}\right.$ value of $51.25 \mathrm{mg} / \mathrm{mL}$ ) (Razavi et al. 2010b). Aviprin (89), isolated from P. uloptera with $\mathrm{RC}_{50}$ of $0.54 \mathrm{mg} /$ $\mathrm{mL}$ was more effective than aviprin-3" $-O$-D-glucopyranoside (90) $\left(\mathrm{RC}_{50}: 5 \mathrm{mg} / \mathrm{mL}\right)$ in the $\mathrm{DPPH}$ assay (Zahri et al. 2012). Among the isolated phytochemicals from aerial parts of $P$. haussknechtii, hydroxy osthol-epoxide (4) was the most potent antioxidant compound with $\mathrm{IC}_{50} \mathrm{~s}$ of 0.048 and $0.043 \mathrm{mM}$ measured by MTT and LPO, respectively (Dissanayake et al. 2017).

\section{Antimicrobial activities}

Extracts, essential oils and pure compounds of Prangos species showed noteworthy antibacterial, antifungal, and antiviral effects. The antibacterial activities of the plant materials have been evaluated mostly by disc diffusion and microtiter broth dilution assays. Remarkably high activities were observed in case of the EO of the leaves of $P$. ferulacea against
Pseudomonas aeruginosa, Staphylococcus epidermidis, S. aureus, and Bacillus cereus strains. Mainly the Gram-positive bacteria (particularly S. aureus and B. cereus) were inhibited by various Prangos species, especially by EOs and methanolic extracts of $P$. ferulacea. $P$. ferulacea, $P$. pabularia and $P$. platychlaena which were active against $C$. albicans.

Antibacterial activities

\section{Crude extracts and essential oils}

The EO of the fruit of $P$. asperula was evaluated for its antibacterial activity and showed a moderate effect against $S$. aureus with a minimum inhibitory concentration (MIC) of $0.128 \mathrm{mg} / \mathrm{mL}$ (Khoury et al. 2018). $S$. aureus was the most susceptible strain against the EO obtained from the aerial parts of $P$. asperula (growth inhibition zone (IZ): $15.0 \mathrm{~mm}$ ), the EO was less active on Escherichia coli (IZ: $11.8 \mathrm{~mm}$ ) and Salmonella enterica (IZ: $3.8 \mathrm{~mm}$ ). The results of the MbD assay reassured these observations (Mneimne et al. 2016).

The acetone extract of the fruit of $P$. denticulata collected from Turkey was characterized with an IZ of $11.9 \mathrm{~mm}$ against Bacillus cereus RSKK 863 (OkeAltuntas et al. 2012).

Among EOs obtained from various organs of $P$. ferulacea, the EO obtained from the leaves was the most active one with the following MIC values: Pseudomonas aeruginosa $(0.0000625 \mathrm{mg} / \mathrm{mL}), S$. epidermidis $(0.00025 \mathrm{mg} / \mathrm{mL})$, and $S$. aureus $(0.0005$ $\mathrm{mg} / \mathrm{mL}$ ), while the EO obtained from the flowers were most active EO against $B$. cereus $(0.0005 \mathrm{mg} / \mathrm{mL})$. The EO obtained from the stem part was less active (Akbari et al. 2010). Razavi et al. (2010a) reported that $B$. cereus (IZ of $15 \mathrm{~mm}$ ) was the most susceptible strain to the EOs of $P$. ferulacea fruits and umbels (Razavi et al. 2010a). EO of P. ferulacea root showed high inhibitory activity against $S$. paratyphi and E. coli with MIC values of 0.01 and $0.005 \mathrm{mg} / \mathrm{mL}$, respectively (Yousefi et al. 2017).

The antimicrobial activities of some medicinal plants used in traditional Turkish cheeses were analysed in an experiment. The methanolic extract of $P$. ferulacea was active against Enterococcus faecalis with a MIC value of $250 \mathrm{mg} / \mathrm{mL}$ (Dagdelen et al. 2014), on other microbes the activity was even less pronounced. The methanol extract of $P$. ferulacea showed moderate antibacterial activity against $B$. 
cereus, B. subtilis, Micrococcus luteus, and S. aureus with IZs of 12-18 mm (Durmaz et al. 2006). Gheisari et al. (2016) investigated the antibacterial activities of the methanolic extracts from the aerial parts of $P$. ferulacea by two methods. Using the disc diffusion method, $C$. freundii was the most susceptible strain with an IZ value of $12.76 \mathrm{~mm}$. Furthermore, these results were supported by the microtiter broth dilution method, where the extract exerted $99 \%$ inhibition on the growth after $24 \mathrm{~h}$ (Gheisari et al. 2016). Methanolic and ethanolic extracts of $P$. ferulacea showed more significant activity against Listeria monocytogenes serotype $4 \mathrm{ab}$ with IZs of 13 and $11 \mathrm{~mm}$, respectively, compared to its aqueous and $n$-hexane extracts having no activity (Sagun et al. 2006).

The antibacterial activities of roots, flowers, leaves, stems, and seeds of $P$. ferulace $a$ and P. uloptera were analysed using disc diffusion assay. The methanolic extracts of the roots of both species possessed high activity with MIC values of $\leq 0.25-1 \mathrm{mg} / \mathrm{mL}$ against the tested strains including $S$. aureus, $S$. pyogenes, $B$. subtilis, E. coli, S. enterica, and Serratia marcescens (Nosrati and Behbahani 2016). EO of P. ferulacea indicated a significant activity against $E$. faecalis (IZ: $23 \mathrm{~mm}$ ) compared to gentamicin (IZ: $8 \mathrm{~mm}$ ) as positive control (Nazemisalman et al. 2018).

In a study carried out with different extracts of $P$. hulusii roots collected in Turkey, the most potent antibacterial activity was attributed to the dichloromethane extract of the plant on E. coli with a MIC value of $0.156 \mathrm{mg} / \mathrm{mL}$ (Tan et al. 2017). Yazici et al. (2013) reported that $P$. hulusii possessed no activity against $S$. aureus, E. coli, Klebsiella pneumoniae, $B$. cereus, and Proteus vulgaris (Yazici et al. 2013).

The hydro-distilled EO of $P$. pabularia fruits demonstrated antibacterial activity against two Gram-positive [S. epidermidis and methicillin-resistant S. aureus (MRSA)], and four Gram-negative bacteria (E. coli, P. aeruginosa, P. vulgaris, and Salmonella typhimurium), and antifungal activity against $C$. albicans; while among the studied microorganisms the most susceptible was the MRSA (clinical isolate, MIC: $0.00125 \mathrm{mg} / \mathrm{mL}$ ) (Özek et al. 2007).

In another study, the EO of $P$. peucedanifolia leaves was active against $S$. mutans, $S$. pyogenes, and $S$. aureus with MIC values less than $1.9 \mathrm{mg} / \mathrm{mL}$, whereas the EO of the fruits was less active (Brusotti et al. 2013).
The evaluation of the antibacterial properties of EOs of fruits of $P$. platychlaena and $P$. uechtritzii revealed high activities against $E$. coli (MIC: $9 \mathrm{mg}$ / $\mathrm{mL}$ ) and B. subtilis (MIC: $36 \mathrm{mg} / \mathrm{mL}$ ), respectively (Uzel et al. 2006).

Among different extracts ( $n$-hexane, methanol, and dichloromethane) obtained from $P$. uloptera roots, the dichloromethane fraction demonstrated the most pronounced antibacterial effect against $S$. aureus analysed by the disc diffusion method (IZ: $15.8 \mathrm{~mm}$ ); whereas no activity was observed against $E$. coli. Microbroth dilution assay reassured these results, where the highest and lowest activity was observed on $S$. aureus and $E$. coli, respectively (Razavi et al. 2010c).

Pure compounds

Oxypeucedanin (48) and imperatorin (44) isolated from the chloroform extract of $P$. platychlaena showed slight activity against E. coli (MIC of 0.048 $\mathrm{mg} / \mathrm{mL}$ ) (Ulubelen et al. 1995), whereas oxypeucedanin (48) was not active against the plant pathogen bacteria Xanthomonas compestris and Erwinia cartovorum (Razavi et al. 2010b).

Compounds isolated from $P$. uloptera were subjected to antimicrobial screening, and 8-geranyloxy psoralen (32) was found to be effective against $S$. epidermidis with a MIC value of $100 \mathrm{mg} / \mathrm{mL}$ (Razavi et al. 2009a). In another study, isoarnottinin $4^{\prime}$ glucoside (28) isolated from P. uloptera possessed high antibacterial activity (particularly against $E$. carotovora with a MIC value of $0.1 \mathrm{mg} / \mathrm{mL}$ ) (Razavi et al. 2011b).

From ten isolated prenylated coumarins of $P$. hulusii, the new coumarin $4^{\prime}$-senecioiloxyosthol (20), showed the highest activity against a series of bacteria and was especially active against $B$. subtilis (MIC of $0.005 \mathrm{mg} / \mathrm{mL}$ ) (Tan et al. 2017).

Osthol (3), isolated from $P$. pabularia exerted a remarkable effect against MRSA and $P$. aeruginosa (MIC values of $0.031 \mathrm{mg} / \mathrm{mL}$ ) compared to the other tested compounds (Tada et al. 2002).

Antifungal activities

Some natural products can permanently damage fungal cell membrane by increasing permeability and fluidity. The subsequent degradation of lipids, proteins and nucleic acids along with the coagulation 
of the cellular components results in the breakdown and death of fungal cells (Yoon et al. 2000). Several studies demonstrated that Prangos species possess antifungal activity against Gram-positive and Gramnegative fungi.

\section{Crude extracts and essential oils}

The EO of $P$. asperula fruits showed remarkable antifungal activity against Trichophyton rubrum and Trichophyton tonsurans with MICs of $0.064 \mathrm{mg} / \mathrm{mL}$ in both strains (Khoury et al. 2018). The EO obtained from the aerial parts of $P$. asperula inhibited the growth of Trichophyton mentagrophytes, Aspergillus fumigatus, and C. albicans, with IZ values of $7.3 \mathrm{~mm}$, $9.1 \mathrm{~mm}$, and $1.9 \mathrm{~mm}$, respectively (Mneimne et al. 2016).

Yousefi et al. (2017) reported that the EO of the roots of $P$. ferulacea had inhibitory activity on $C$. albicans (MIC: $0.005 \mathrm{mg} / \mathrm{mL}$ ) (Yousefi et al. 2017). The methanolic extract of this species did not inhibit growth of C. albicans (Dagdelen et al. 2014). The EO of $P$. ferulacea obtained at flowering stage significantly inhibited the growth of Sclerotinia sclerotiorum mycelia at doses exceeding $0.01 \mathrm{mg} / \mathrm{mL}$; the inhibition was approximately $55 \%$ at $1.5 \mathrm{mg} / \mathrm{mL}$ concentration (Razavi 2012a). The EO obtained from fruits and umbels of $P$. ferulacea demonstrated an activity with 9-12 $\mathrm{mm}$ of inhibition against $C$. kefyr (Razavi et al. 2010a). By applying microbroth dilution method, the hydroalcoholic extract of $P$. ferulacea showed a weak effect (MIC: $>1000 \mathrm{mg} / \mathrm{mL}$ ) against C. albicans (Dagdelen et al. 2014).

When assessing antifungal activity of EO of $P$. pabularia fruits, significant activity was observed against C. albicans (MIC: $0.0025 \mathrm{mg} / \mathrm{mL}$ ) (Özek et al. 2007).

Brusotti et al. (2013) reported that the EO of $P$. peucedanifolia flowers has remarkable antifungal activity against Trichophyton rubrum with a MIC value of $2.4 \mathrm{mg} / \mathrm{mL}$ comparable to that of ampicillin (MIC: $0.5 \mathrm{mg} / \mathrm{mL}$ ) (Brusotti et al. 2013).

The EOs yielded from fruits of $P$. platychlaena and $P$. uechtritzii had marginal activities against $C$. albicans, $C$. krusei, and C. tropicalis with MIC values exceeding $72 \mathrm{mg} / \mathrm{mL}$ (Uzel et al. 2006). The decoction (drug-extract ratio 1:2 w/v) of $P$. uechtritzii showed potent inhibitory activity at concentration of $80 \%$ on the growth of Alternaria alternata, Aspergillus parasiticus, and Penicillium digitatum with 57, 29, and $71 \%$ inhibition, respectively; however, no inhibitory activity was found against Aspergillus niger (Ozcan 1999).

Furthermore, the EO of the fruit of P. platychlaena had no antifungal activities against three Colletotrichum species. Nona-(2S)-3,5-diyn-2-yl acetate (134) from the EO and its semisynthetic derivative (2S)-3,5-nonadiyn-2-ol were also inactive against the above-mentioned fungi (Tabanca et al. 2018).

\section{Pure compounds}

A good antifungal effect (MIC $>0.4 \mathrm{mg} / \mathrm{mL}$ ) of isoarnottinin $4^{\prime}$-glucoside (28) was revealed against $S$. sclerotiorum and C. kefyer (Razavi et al. 2011b).

In the study of Ulubelen et al. (1995) both oxypeucedanin (48) and imperatorin (44), isolated from $P$. platychlaena, showed strong antifungal activities against $C$. albicans with MICs of 0.054 $\mathrm{mg} / \mathrm{mL}$ (Ulubelen et al. 1995).

8-Geranyloxy psoralen (32) isolated from $P$. uloptera has been reported to possess very weak activity against $C$. kruzei and $C$. kefyr, with MIC values of 300 and $100 \mathrm{mg} / \mathrm{mL}$, respectively (Razavi et al. 2009a).

Quercetin-3-O-glucoside (98) isolated from $P$. ferulacea had no activity against $C$. kefyr (Razavi et al. 2009c). Oxypeucedanin (48) isolated form leaf extract of $P$. uloptera was found to be inactive against S. sclerotorium (Razavi et al. 2010b).

Antiviral activities

\section{Crude extract}

Antiviral activities of the ethanolic extracts of $P$. asperula leaf and seed samples were assessed against herpes simplex virus type 1 (HSV-1) and a moderate potency was demonstrated $\left(\mathrm{IC}_{50}: 0.66 \mathrm{mg} / \mathrm{mL}\right)$ compared to acyclovir $\left(\mathrm{IC}_{50}: 0.00377 \mathrm{mM}\right)$ (Saab et al. 2012).

\section{Pure compounds}

From a series of coumarins isolated from P. tschimganica, psoralen (31) was identified as the most effective compound. It inhibited the replication of human immunodeficiency virus type 1 (HIV-1) (IIIB 
Strain) in $\mathrm{H} 9$ lymphocytes $\left(\mathrm{EC}_{50}: 0.0001 \mathrm{mg} / \mathrm{mL}\right)$ and inhibited the growth of uninfected $\mathrm{H} 9$ cells $\left(\mathrm{IC}_{50}\right.$ : $0.0191 \mathrm{mg} / \mathrm{mL}$ ) with $\mathrm{IC}_{50}$ and $\mathrm{EC}_{50}$ values comparable to those of the active control azidothymidine $\left(\mathrm{EC}_{50}:<0.001 \mathrm{mg} / \mathrm{mL} ; \mathrm{IC}_{50}: 500 \mathrm{mg} / \mathrm{mL}\right.$ ) (Shikishima et al. 2001a).

Anti-herpes virus effects of the coumarins isolated from $P$. ferulacea were analysed on a confluent monolayer of Vero cells (an African green monkey kidney cell line) infected with 25 PFU (plaqueforming units) of HSV-1. None of the analysed coumarins possessed anti-HSV activity at non-toxic concentrations on Vero cells (Shokoohinia et al. 2014).

\section{Phytotoxic activity}

Phytotoxicity is the ability of plant to inhibit of plant growth, delay of seed germination or prevention of the other adverse effects caused by phytotoxins (Blok et al. 2019). The extracts, EOs, and isolated phytochemicals from three Prangos species including $P$. ferulacea, $P$. pabularia, and $P$. uloptera have been previously subjected to possess possible phytotoxicity by analysis of their potency in prohibition of growth of lettuce and Trifolium resupinatum.

Among aqueous and hydro-alcoholic extracts obtained from different plant parts (leaf, flower and shoot) of $P$. ferulacea, the hydro-alcoholic extract of the flowers showed phytotoxic effect by increasing the proline content and decreasing seedling growth and seed germination of Trifolium resupinatum (Bazdar and Sadeghi 2018; Sadeghi and Bazdar 2018). The EO of $P$. ferulacea obtained during the flowering period inhibited lettuce seed germination with an inhibition value of $97.0 \%$ (Razavi 2012a).

The EO extracted from $P$. pabularia showed strong phytotoxic effect with $\mathrm{IC}_{50}$ values of $0.14,0.11$ and $0.12 \mathrm{mg} / \mathrm{mL}$ for inhibition of the growth of the shoot, seed germination, and root of lettuce, respectively (Razavi 2012b).

The dichloromethane extract of $P$. uloptera exhibited higher stunting effect compared to the $n$-hexane, and methanolic fractions against root growth, seed germination, and shoot elongation of lettuce (Lactuca sativa $\mathrm{L}$. CV. Varamin), with $\mathrm{IC}_{50} \mathrm{~s}$ of $1.85,2.00$, and $2.08 \mathrm{mg} / \mathrm{mL}$, respectively (Razavi et al. 2010c). Oxypeucedanin (48), isolated from P. uloptera exhibited phytotoxic effect by inhibiting the growth of lettuce shoots with an $\mathrm{IC}_{50}$ value of $0.21 \mathrm{mg} / \mathrm{mL}$ (Razavi et al. 2010b). Isoarnottinin 4'-glucoside (28) possessed considerable phytotoxic activity against root elongation of lettuce; whereas the length of the root was decreased from 38.72 to $5.84 \mathrm{~mm}$ at concentrations 0 to $1 \mathrm{mg} / \mathrm{mL}$ of isoarnottinin $4^{\prime}$ glucoside (28), respectively (Razavi et al. 2011b).

Insecticidal and repellent activity

In general, the insecticidal and repellent activities of EOs extracted from $P$. ferulacea, $P$. heyniae, and $P$. platychlaena have been evaluated. They showed a moderate activity comparing to the applied controls.

The EO of $P$. ferulacea was active against the egg stage of Trichogramma embryophagum with an $\mathrm{LC}_{50}$ value of $0.0021 \mathrm{~mL} / \mathrm{L}$ (Sumer Ercan et al. 2013).

$P$. heyniae $\mathrm{EO}$ obtained from four different regions of Turkey possessed moderate larvicidal activity at 0.03125 and $0.062 \mathrm{mg} / \mathrm{mL}$ against Aedes aegypti compared to permethrin $(0.000025 \mathrm{mg} / \mathrm{mL})$ as positive control (Ozek et al. 2018).

The EO gained from $P$. platychlaena collected in Eastern part of Turkey showed repellent activity against female $A$. aegypti L. mosquito with a minimum effective dosage (MED) value of $0.156 \mathrm{mg} / \mathrm{cm}^{2}$ (Tabanca et al. 2018).

Suberosin (6), a coumarin from $P$. pabularia demonstrated moderate mosquito repellent effect compared to $N, N$-diethyl-3-methylbenzamide (DEET) as the positive control. This compound also showed a remarkable larvicidal activity with an $\mathrm{LC}_{50}$ value of $0.008 \mathrm{mg} / \mathrm{mL}$ at $24-\mathrm{h}$ post treatment (Tabanca et al. 2016).

Cytotoxic and antiproliferative activities

The secondary metabolites isolated form plants have been demonstrated promising approach to discover potential drugs to be considered as a complementation of chemotherapeutics treatment (Newman and Cragg 2012). Nowadays, some of the phytochemicals are known for their strong potency as anti-tumour agents. The plants in the genus of Prangos have been subjected to evaluate their effects on various cancer cell lines possessing cytotoxicity and antiproliferation activities. 


\section{Crude extracts and essential oil}

The ethanolic extract of aerial parts of $P$. asperula were investigated for cytotoxic effects on Vero cell line (ATCC: CCL 81) using the MTT assay, and it showed moderated activity with $\mathrm{TC}_{50}$ values higher than $1 \mathrm{mg} / \mathrm{mL}$ (Saab et al. 2012). The antiproliferative activity of the EO obtained from the leaves of $P$. asperula was investigated by the sulphorhodamine B assay, and an $\mathrm{IC}_{50}$ of $0.139 \mathrm{mg} / \mathrm{mL}$ was observed against renal cell adenocarcinoma (Loizzo et al. 2008b).

Rostami et al. (2012) studied the in vitro antiproliferative activity of aqueous extracts of $P$. platychloena by the Trypan Blue exclusion test. The extract was active at concentration of $1 \mathrm{mg} / \mathrm{mL}$ with maximum inhibitions $72 \%$ and $59 \%$ in colorectal cancer cell line (CCL-221) and colon cancer cell line (Caco2), respectively (Rostami et al. 2012).

The dichloromethane extract of P. uloptera roots reduced the viability of HeLa cells after $24 \mathrm{~h}$ with an $\mathrm{IC}_{50} 0.10 \mathrm{mg} / \mathrm{mL} ; 100 \%$ cytotoxicity was recorded at concentrations exceeding $1 \mathrm{mg} / \mathrm{mL}$ (Razavi et al. 2010c).

Remarkable cytotoxic activity was reported for the dichloromethane extract of $P$. pabularia on HeLa cell line $\left(\mathrm{IC}_{50}: 0.52 \mathrm{mg} / \mathrm{mL}\right.$ at $24 \mathrm{~h}$ ) in the MTT assay (Salehi et al. 2016).

Yazici et al. (2013) investigated the cytotoxic activity of various extracts of $P$. hulusii obtained from aerial parts and roots using the MTT and lactate dehydrogenase (LDH) assays. In the MTT assay, the extracts had no effects at the tested concentrations; however, petroleum ether extracts demonstrated low activity in the LDH assay on the rat kidney epithelial cell line (Yazici et al. 2013).

Using the MTT assay, the extracts of $P$. meliocarpoides were not toxic to baby hamster kidney fibroblast cell line (BHK 21) in concentrations of 0.01-0.1 $\mathrm{mg} / \mathrm{mL}$ (Altuntas et al. 2011).

\section{Pure compounds}

Compounds isolated from $P$. ferulacea were tested on human ovarian carcinoma cell line (A2780S) using the MTT assay, and osthol (3) had an $\mathrm{IC}_{50}$ value of $(0.38$ $\mathrm{mM}$, viability of $9.41 \%$ ), while isoimperatorin (45) was less active $\left(\mathrm{IC}_{50}: 1.1 \mathrm{mM}\right.$ ) (Shokoohinia et al. 2014). From the EO of the root part of P. ferulacea 3,5-nonadiyne (133) was isolated, and this compound exhibited no activity against Thymic $\mathrm{T}$ lymphocytes rat cell line (Dokovic et al. 2004). The isolated quercetin 3-O-glucoside (98) from $P$. ferulacea showed no activity against McCoy cell line evaluated by MTT assay (Razavi et al. 2009c).

In a further experiment, osthol (3) was found to be the most active compound against lung (NCI-H322 and A549), melanoma (A375), prostate (PC-3), colon (HCT-116), and epidermoid carcinoma (A431) cell lines compared to other compounds from P. pabularia. Osthol (3) had $\mathrm{IC}_{50}$ values of $0.0145,0.0032$, and $0.0302 \mathrm{mM}$, for lung (A549), epidermoid carcinoma (A431), and colon (HCT-116) cell lines, respectively (Farooq et al. 2014a). Farooq et al. (2018) measured the cytotoxicity of the semi-synthesized analogues of osthol (3) using the MTT method. Among all the tested compounds, $N$-(2-methylpropyl)-3-\{4 methoxy-3-(3-methylbut-2-enyl)-2-(prop-2-en-1-oxy)phenyl $\}$ prop-2-en-1-amide exhibited the best results against leukaemia cell line (THP1) with an $\mathrm{IC}_{50}$ of $0.005 \mathrm{mM}$ (Farooq et al. 2018). Numonov et al. (2018) reported that the coumarin yuganin A (22), isolated for the first time from $P$. pabularia improved the proliferation of B16 melanoma cells; while the cell viability was $127.90 \%$ at concentration of $0.05 \mathrm{mM}$ and the intracellular melanin content was significantly increased (Numonov et al. 2018).

In a study carried out by Razavi et al. (2009a), 8-geranyloxy psoralen (32) isolated from $P$. uloptera showed a good potency in reducing the viability of $\mathrm{HeLa}$ and Mc-Coy cell lines with $\mathrm{IC}_{50}$ values of 0.792 and $0.835 \mathrm{mM}$, respectively, determined by the MTT assay, and $\mathrm{IC}_{50}$ of $1.26 \mathrm{mM}$ for Mc-Coy cell line evaluated by Tripan blue assay (Razavi et al. 2009b). Oxypeucedanin (48) and isoarnottinin 4'-glucoside (28) isolated from P. uloptera exhibited strong to moderate cytotoxic effects against $\mathrm{HeLa}$ cells with $\mathrm{IC}_{50}$ values of $0.314 \mathrm{mg} / \mathrm{mL}$ and $0.84 \mathrm{mg} / \mathrm{mL}$, respectively (Razavi et al. 2010b, 2011b).

An MTT assay revealed that aviprin (89) inhibited $\mathrm{HeLa}$ and prostate cancer $(\mathrm{LNCaP})$ cells with $\mathrm{IC}_{50}$ values of 0.265 and $0.411 \mathrm{mg} / \mathrm{mL}$, respectively; whilst aviprin- $3^{\prime}$ - $O$-D-glucopyranoside (90) showed mild effects on the above-mentioned cell lines, with $\mathrm{IC}_{50}$ values of 0.335 and $6.632 \mathrm{mg} / \mathrm{mL}$, respectively (Zahri et al. 2012). 
Anti-inflammatory effect

Inflammation is defined as the body response to defend against allergens and/or injury of the tissues, while they can cause various disorders (e.g. allergies, cardiovascular dysfunctions, metabolic syndrome, cancer, and autoimmune diseases) (Ghasemian et al. 2016). In order to decrease the adverse effects of the available anti-inflammatory drugs, the natural drugs can be promoted to replace. The plants are rich sources of natural products, considering they have been used in traditional medicine as natural anti-inflammatory agents. Among the Prangos species, the extracts of $P$. platychloena and isolated coumarins from $P$. haussknechtii have been assessed for their antiinflammatory effects.

Aqueous extract of $P$. platychloena decreased the secretion of interleukin 8 (IL-8) in colorectal cancer cell line (CCL-221) from 519.07 to $28.3 \mathrm{pg} / \mathrm{mL}$, while the methanolic extract reduced its secretion to 92.73 $\mathrm{pg} / \mathrm{mL}$; and the secretion of interleukin 6 (IL-6) was decreased from 63 to 1 and $4 \mathrm{pg} / \mathrm{mL}$ using the aqueous and methanolic extract, respectively (Rostami et al. 2012).

Coumarins isolated from $P$. haussknechtii inhibited cyclooxygenase enzymes (COX-1 and COX-2) with $\mathrm{IC}_{50}$ values ranging from 0.0368 to $0.0564 \mathrm{mM}$ comparable to NSAIDs including aspirin $\left(\mathrm{IC}_{50}\right.$ of 0.6 $\mathrm{mM}$ for COX-1), naproxen $\left(\mathrm{IC}_{50}\right.$ of $0.0522 \mathrm{mM}$ for COX-1, and -2), and ibuprofen ( $\mathrm{IC}_{50}$ of $0.0728 \mathrm{mM}$ for COX-1) (Dissanayake et al. 2017).

\section{Anti-hypertensive effect}

The angiotensin converting enzyme (ACE) inhibitory activity of different $P$. asperula extracts was tested in vitro, and only the $n$-hexane fraction was found to be active with an $\mathrm{IC}_{50}$ of $0.150 \mathrm{mg} / \mathrm{mL}$ (Loizzo et al. 2008a). The hydroalcoholic extract of $P$. ferulacea exhibited a weak inhibition of ACE with $\mathrm{IC}_{50}$ value of $4.057 \mathrm{mg} / \mathrm{mL}$ (Namjoyan et al. 2015).

\section{Antidiabetic effects}

The methanolic extract of $P$. asperula had no effects on $\alpha$-amylase and $\alpha$-glucosidase enzymes (Loizzo et al. 2008a). In the same assay, the EO of P. gaubae possessed the higher inhibitory activity against $\alpha$ amylase (1.35 mmol acarbose equivalent (AE)/g oil), and $\alpha$-glucosidase (38.84 mmol AEs/g oil) in comparison with its dichloromethane, methanol, and $n$ hexane extracts (Bahadori et al. 2017b).

\section{Neuroprotective effect}

The EO and dichloromethane extract of $P$. gaubae possessed the highest neuroprotective effects when compared to $n$-hexane, and methanolic soluble-extracts against acetylcholinesterase (AChE) and butyryl-cholinesterase (BChE) enzymes with inhibition values of 2.97 and $3.51 \mathrm{mg}$ galanthamine equivalent $(\mathrm{GE}) / \mathrm{g}$, respectively (Bahadori et al. 2017a). In a similar work, various extracts of $P$. ferulacea were tested and the $n$-hexane fraction had the highest $\mathrm{AChE}$ inhibitory activity $\left(75.6 \%\right.$ at $\mathrm{IC}_{50}$ : $0.05 \mathrm{mg} / \mathrm{mL}$ ). The furocoumarin heraclenin $(\mathbf{6 0})$ isolated from the above-mentioned $n$-hexane fraction showed the highest activity among the studied compounds with an $\mathrm{IC}_{50}$ value of $0.0568 \mathrm{mg} / \mathrm{mL}$ (AbbasMohammadi et al. 2018).

\section{Abortifacient effect}

In an in vivo study, the hydroalcoholic and aqueous extracts of $P$. ferulacea leaves were administered orally to 60 pregnant rats at different doses $(25,50$, $100,300,500$, and $1000 \mathrm{mg} / \mathrm{g}$ per day). No significant effect on abortion frequency was detected; however, the abortion rate was slightly and dose-independently increased by taking the hydroalcoholic extract (Kazerooni and Mousavizadeh 2005; Kazerooni et al. 2006).

Miscellaneous bioactivities

The EO of $P$. gaubae inhibited lipase enzyme activity [1.59 mmol orlistat equivalent $(\mathrm{OE}) / \mathrm{g}$ ] which might indicate an anti-obesity effect. The $n$-hexane extract of $P$. gaubae was more active than the dichloromethane and methanolic extracts against tyrosinase enzyme activity [36.33 mg kojic acid equivalent (KAE)/g], therefore, it seems to be worth for further testing as a natural skin-care agent (Bahadori et al. 2017a).

Regarding the glutathione-S-transferase (GST) activity, the methanolic extract obtained from the aerial parts of $P$. ferulacea was the most effective inhibitor from the studied plants (Chaerophyllum macropodum Boiss. and Heracleum persicum Desf.) 
with an $\mathrm{IC}_{50}$ value of $0.079 \mathrm{mg} / \mathrm{mL}$ (Çoruh et al. 2007).

Several compounds, including coumarins and $\gamma$ pyrone derivatives isolated from $P$. pabularia inhibited the release of cytokines interleukin (IL-2, IL-4, and IL-1 $\beta$ ) and tumour necrosis factor (TNF- $\alpha$ ) which indicates potential anti-inflammatory effects (Tada et al. 2002).

3,5-Nonadiyne (133) isolated from the EO of the root part of $P$. ferulacea exhibited a concentrationdependent inhibition on endogenous nitric oxide release on rat peritoneal macrophages with an $\mathrm{IC}_{50}$ of $0.0067 \mathrm{mM}$ (Dokovic et al. 2004).

\section{Phytochemistry}

Phytochemicals are produced in higher plants as secondary metabolites, considering their crucial roles in plants (e.g. defending against herbivores, preserving under stress conditions, attracting of pollinators, etc.), their bioactivities for human are also considerable. In order to discover the potent natural drugs, isolation and identification of phytoconstituents are vital.

16 species of the Prangos genus have been studied for their secondary metabolites. Various coumarin derivatives have been isolated and identified as the major secondary metabolites of this genus. Overall, 30 simple coumarins (1-30), 66 linear and angular furocoumarins (31-96), six flavonoids (97-102), 16 terpenoids (103-118), seven $\gamma$-pyrones (119-125), three phytosterols (129-131), and eight other compounds $(\mathbf{1 2 6}, \mathbf{1 2 7}, \mathbf{1 2 8}, \mathbf{1 3 2}-\mathbf{1 3 6})$ have been isolated from different products of the Prangos genus. Totally 131 non-volatile natural products have been reported. These secondary metabolites along with the applied plant parts and plant products are listed in Table S3 and their chemical structures are shown in Fig. 1.

\section{Coumarins}

Coumarins have been isolated from hundreds of plants species distributed in more than 40 different families with diversity of 1300 types. Families with occurrence numbers of $>100$ are identified as Apiaceae (Umbelliferae), Rutaceae, Asteraceae (Compositae), Fabaceae (Leguminosae), Oleaceae, Moraceae, and Thymelaeaceae, respectively (Ribeiro and Kaplan
2002). Apiaceae is the major and most diverse source of coumarins, containing five major types of coumarin derivatives including simple coumarins, linear and angular furocoumarins, linear and angular pyranocoumarins (Ribeiro and Kaplan 2002; Kontogiorgis and Hadjipavlou-Litina 2003). So far, from the Prangos genus simple coumarins, linear and angular, glycosylated, and condensed furocoumarins, along with linear dihydro-furocoumarin derivatives have been identified.

\section{Simple coumarins}

Farooq et al. (2014a) isolated the simple coumarins umbelliferon (1), 6-hydroxycoumarin (2), osthol (3), and meranzin (11) from $P$. pabularia (Farooq et al. 2014a). Suberosin (6) (Tabanca et al. 2016), ulopterol (8), auraptenol (10), paniculal (14), tamarin (25) (Tada et al. 2002), and a new coumarin yuganin A (22) (Numonov et al. 2018) were also isolated and identified from this species.

A new coumarin $4^{\prime}$-senecioiloxyosthol (20), along with hydroxyl-osthol-epoxide (4), murraol (15), and macrocarpin (22) were isolated from $P$. hulusii roots (Tan et al. 2017).

From $P$. tschimganica, osthenol (5), demethyl-7 suberosin (7), scopoletin (9), isomeranzin (13), peucedanol (18), yuehgesin-B (19), and a new coumarin glycoside tschimganic ester A (30) have been isolated (Shikishima et al. 2001b).

Two novel prenylated coumarins 2-oxo-2H-1-benzopyran-8-yl-2-methyl-2-buten-1-yl ester (23) and butanoic acid, 3-methyl,(2E)-4-(7-methoxy-2-oxo2H-1-benzopyran-8-yl)-2-methyl-2-buten-1-yl ester (24) were also isolated from aerial portions of $P$. haussknechtii (Dissanayake et al. 2017).

In a study performed by Abyshev (1974), ferudenol (16), ferudiol (17), and prangone (26) were isolated from the root part of $P$. ferulacea (Abyshev 1974).

A new coumarin glycoside 6- $O$-[ $\beta$-D-apiofuranosyl-(1 $\rightarrow$ 6)- $\beta$-D-glucopyranosyl]-prenyletin (27), and two known coumarin glycosides [tortuoside (27), and isoarnottinin $4^{\prime}$-glucoside (28)] were obtained from the methanolic extract of $P$. uloptera roots (Razavi et al. 2008a, 2011b). 
1460

Phytochem Rev (2020) 19:1449-1470<smiles>Cc1c(C)c(C)c2oc(=O)ccc2c1C</smiles>

$1 R_{1}=H ; R_{2}=H ; R_{3}=O H ; R_{4}=H$
$2 R_{1}=H ; R_{2}=O H ; R_{3}=H ; R_{4}=H$

$3 \mathrm{R}_{1}=\mathrm{H} ; \mathrm{R}_{2}=\mathrm{H} ; \mathrm{R}_{3}=\mathrm{OMe} ; \mathrm{R}_{4}=\mathrm{CH}_{2} \mathrm{CHC}(\mathrm{Me})_{2}$

$4 \mathrm{R}_{1}=\mathrm{H} ; \mathrm{R}_{2}=\mathrm{H} ; \mathrm{R}_{3}=\mathrm{OMe} ; \mathrm{R}_{4}=\mathrm{CH}(\mathrm{OH}) \mathrm{CH}(\mathrm{O}) \mathrm{C}(\mathrm{Me})_{2}$

$5 \mathrm{R}_{1}=\mathrm{H} ; \mathrm{R}_{2}=\mathrm{H} ; \mathrm{R}_{3}=\mathrm{OH} ; \mathrm{R}_{4}=\mathrm{CH}_{2} \mathrm{CHC}(\mathrm{Me})_{2}$

$6 \mathrm{R}_{1}=\mathrm{H} ; \mathrm{R}_{2}=\mathrm{CH}_{2} \mathrm{CHC}(\mathrm{Me})_{2} ; \mathrm{R}_{3}=\mathrm{OMe} ; \mathrm{R}_{4}=\mathrm{H}$

$7 \mathrm{R}_{1}=\mathrm{H} ; \mathrm{R}_{2}=\mathrm{OH} ; \mathrm{R}_{3}=\mathrm{CH}_{2} \mathrm{CHC}(\mathrm{Me})_{2} ; \mathrm{R}_{4}=\mathrm{H}$

$8 \mathrm{R}_{1}=\mathrm{H} ; \mathrm{R}_{2}=\mathrm{CH}_{2} \mathrm{CH}(\mathrm{OH}) \mathrm{C}(\mathrm{OH})(\mathrm{Me})_{2} ; \mathrm{R}_{3}=\mathrm{OMe} ; \mathrm{R}_{4}=\mathrm{H}$

$9 \mathrm{R}_{1}=\mathrm{H} ; \mathrm{R}_{2}=\mathrm{OMe} ; \mathrm{R}_{3}=\mathrm{OH} ; \mathrm{R}_{4}=\mathrm{H}$

$10 \mathrm{R}_{1}=\mathrm{H} ; \mathrm{R}_{2}=\mathrm{H} ; \mathrm{R}_{3}=\mathrm{OMe} ; \mathrm{R}_{4}=\mathrm{CH}_{2} \mathrm{CH}(\mathrm{OH}) \mathrm{C}\left(\mathrm{CH}_{2}\right)(\mathrm{Me})$

$11 \mathrm{R}_{1}=\mathrm{H} ; \mathrm{R}_{2}=\mathrm{H} ; \mathrm{R}_{3}=\mathrm{OMe} ; \mathrm{R}_{4}=\mathrm{CH}_{2} \mathrm{CH}(\mathrm{O}) \mathrm{C}(\mathrm{O})(\mathrm{Me})_{2}$

$12 \mathrm{R}_{1}=\mathrm{H} ; \mathrm{R}_{2}=\mathrm{H} ; \mathrm{R}_{3}=\mathrm{OMe} ; \mathrm{R}_{4}=\mathrm{CH}_{2} \mathrm{CH}(\mathrm{OH}) \mathrm{C}(\mathrm{OH})(\mathrm{Me})_{2}$

$13 \mathrm{R}_{1}=\mathrm{H} ; \mathrm{R}_{2}=\mathrm{H} ; \mathrm{R}_{3}=\mathrm{OMe} ; \mathrm{R}_{4}=\mathrm{CH}_{2} \mathrm{C}(\mathrm{O}) \mathrm{CH}(\mathrm{Me})_{2}$

$14 \mathrm{R}_{1}=\mathrm{H} ; \mathrm{R}_{2}=\mathrm{H} ; \mathrm{R}_{3}=\mathrm{OMe} ; \mathrm{R}_{4}=\mathrm{CHO}$

$15 \mathrm{R}_{1}=\mathrm{H} ; \mathrm{R}_{2}=\mathrm{H} ; \mathrm{R}_{3}=\mathrm{OMe} ; \mathrm{R}_{4}=\mathrm{CHCHC}(\mathrm{OH})(\mathrm{Me})_{2}$

$16 \mathrm{R}_{1}=\mathrm{H} ; \mathrm{R}_{2}=\mathrm{H} ; \mathrm{R}_{3}=\mathrm{OMe} ; \mathrm{R}_{4}=\mathrm{OCH}_{2} \mathrm{CH}(\mathrm{OH}) \mathrm{C}\left(\mathrm{CH}_{2}\right)(\mathrm{Me})$

$17 \mathrm{R}_{1}=\mathrm{H} ; \mathrm{R}_{2}=\mathrm{H} ; \mathrm{R}_{3}=\mathrm{OH} ; \mathrm{R}_{4}=\mathrm{CH}_{2} \mathrm{CH}\left(\mathrm{C}(\mathrm{OH})(\mathrm{Me})_{2}\right) \mathrm{C}(\mathrm{O}) \mathrm{CHC}(\mathrm{Me})_{2}$

$18 \mathrm{R}_{1}=\mathrm{H} ; \mathrm{R}_{2}=\mathrm{CH}_{2} \mathrm{CH}(\mathrm{OH}) \mathrm{C}(\mathrm{OH})(\mathrm{Me})_{2} ; \mathrm{R}_{3}=\mathrm{OMe} ; \mathrm{R}_{4}=\mathrm{H}$

$19 \mathrm{R}_{1}=\mathrm{H} ; \mathrm{R}_{2}=\mathrm{H} ; \mathrm{R}_{3}=\mathrm{OMe} ; \mathrm{R}_{4}=\mathrm{CH}_{2} \mathrm{CH}(\mathrm{OH}) \mathrm{C}(\mathrm{Me})_{2} \mathrm{OC}(\mathrm{Me})_{2} \mathrm{OH}$

$20 \mathrm{R}_{1}=\mathrm{H} ; \mathrm{R}_{2}=\mathrm{H} ; \mathrm{R}_{3}=\mathrm{OMe} ; \mathrm{R}_{4}=\mathrm{CH}_{2} \mathrm{CHC}(\mathrm{Me}) \mathrm{CH}_{2} \mathrm{OC}(\mathrm{O}) \mathrm{CHC}(\mathrm{Me})_{2}$

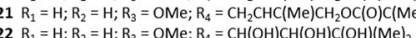
$23 \mathrm{R}_{1}=\mathrm{H} ; \mathrm{R}_{2}=\mathrm{H} ; \mathrm{R}_{3}=\mathrm{OMe} ; \mathrm{R}_{4}=\mathrm{CH}_{2} \mathrm{CHC}\left((\mathrm{Me}) \mathrm{CH}_{2} \mathrm{OC}(\mathrm{O}) \mathrm{CHC}(\mathrm{Me})_{2}\right)$ $\left.24 \mathrm{R}_{1}=\mathrm{H} ; \mathrm{R}_{2}=\mathrm{H} ; \mathrm{R}_{3}=\mathrm{OMe} ; \mathrm{R}_{4}=\mathrm{CH}_{2} \mathrm{CHC}(\mathrm{Me}) \mathrm{CH}_{2} \mathrm{OC}(\mathrm{O}) \mathrm{CH}_{2} \mathrm{CH}(\mathrm{Me})_{2}\right)$ $25 \mathrm{R}_{1}=\mathrm{H} ; \mathrm{R}_{2}=\mathrm{CH}_{2} \mathrm{CH}(\mathrm{OH}) \mathrm{C}\left(\mathrm{CH}_{2}\right)(\mathrm{Me}) ; \mathrm{R}_{3}=\mathrm{OMe} ; \mathrm{R}_{4}=\mathrm{H}$ $26 R_{1}=H ; R_{2}=H ; R_{3}=O M e ; R_{4}=C_{2} C(O) C\left(C_{2}\right)(M e)$
$27 R_{1}=H ; R_{2}=H ; R_{3}=O H ; R_{4}=C_{2} C H(O H) C(M e)_{2}(\beta$-D-glucosyl) $28 R_{1}=H ; R_{2}=H ; R_{3}=O H ; R_{4}=C_{2} C H C(M e) C_{2} \mathrm{OGlu}$

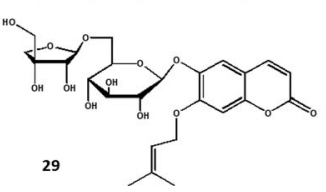

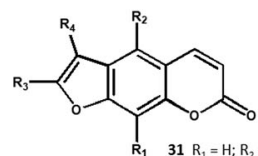

$31 \mathrm{R}_{1}=\mathrm{H} ; \mathrm{R}_{2}=\mathrm{H} ; \mathrm{R}_{3}=\mathrm{H} ; \mathrm{R}_{4}=\mathrm{H}$ $32 \mathrm{R}_{1}-\mathrm{OCH}_{2} \mathrm{CHC}\left((\mathrm{Me})\left(\mathrm{CH}_{2} \mathrm{CH}_{2} \mathrm{CHC}(\mathrm{Me})_{2}\right) ; \mathrm{R}_{2}=\mathrm{H} ; \mathrm{R}_{3}=\mathrm{H} ; \mathrm{R}=\mathrm{H}\right.$ $33 \mathrm{R}_{1}=\mathrm{H} ; \mathrm{R}_{2}=\mathrm{OCH}_{2} \mathrm{CH}(\mathrm{OH}) \mathrm{C}(\mathrm{Me})_{2} \mathrm{Cl}_{3} \mathrm{R}_{3}=\mathrm{H} ; \mathrm{R}_{4}=\mathrm{H} ; \mathrm{R}_{3}=\mathrm{H} ; \mathrm{R}_{4}=\mathrm{H}$ $34 \mathrm{R}_{1}=\mathrm{OCH}_{2} \mathrm{CH}(\mathrm{OH}) \mathrm{C}(\mathrm{Me})_{2} \mathrm{Cl} ; \mathrm{R}_{2}=\mathrm{H} ; \mathrm{R}_{3}=\mathrm{H} ; \mathrm{R}_{4}=\mathrm{H}$ $35 \mathrm{R}_{1}=\mathrm{OCH}_{2} \mathrm{CH}\left(\mathrm{C}(\mathrm{OH})(\mathrm{Me})_{2}\right)\left(\mathrm{OC}(\mathrm{O}) \mathrm{CH}_{2} \mathrm{CH}(\mathrm{Me})_{2}\right) ; \mathrm{R}_{2}=\mathrm{H} ; \mathrm{R}_{3}=\mathrm{H} ; \mathrm{R}_{4}=\mathrm{H}$ $37 \mathrm{R}_{1}=\mathrm{OH} ; \mathrm{R}_{2}=\mathrm{H} ; \mathrm{R}_{3}=\mathrm{H} ; \mathrm{R}_{4}=\mathrm{H}$ $38 R_{1}=H ; R_{2}=O M e ; R_{3}=H ; R_{4}=H$ $39 \mathrm{R}_{1}=\mathrm{H} ; \mathrm{R}_{2}=\mathrm{OH} ; \mathrm{R}_{3}=\mathrm{H} ; \mathrm{R}_{4}=\mathrm{H}$ $42 \mathrm{R}_{1}=\mathrm{OCH}_{2} \mathrm{CH}(\mathrm{OH}) \mathrm{C}\left(\mathrm{CH}_{2}\right)(\mathrm{Me}) \mathrm{H} ; \mathrm{R}_{2}=\mathrm{H} ; \mathrm{R}_{3}=\mathrm{H} ; \mathrm{R}_{4}=\mathrm{H}$ $89 \mathrm{R}_{1}=\mathrm{H} ; \mathrm{R}_{2}=\mathrm{OCH}_{2} \mathrm{CH}(\mathrm{OH}) \mathrm{C}(\mathrm{OH})(\mathrm{Me})_{2} ; \mathrm{R}_{3}=\mathrm{H} ; \mathrm{R}_{4}=\mathrm{H}$

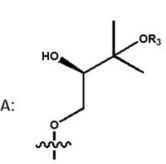

B:

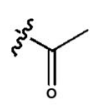

$52 \mathrm{R}_{1}=\mathrm{H} ; \mathrm{R}_{2}=\mathrm{A} ; \mathrm{R}_{3}=\mathrm{H}$

$53 R_{1}=H ; R_{2}=A ; R_{3}=B$ $41 \mathrm{R}_{1}=\mathrm{H} ; \mathrm{R}_{2}=\mathrm{OCH} \mathrm{O}_{2} \mathrm{CH}(\mathrm{OH}) \mathrm{C}\left(\mathrm{CH}_{2}\right)(\mathrm{Me}) ; \mathrm{R}_{3}=\mathrm{H} ; \mathrm{R}_{4}=\mathrm{H}$ $44 \mathrm{R}_{1}=\mathrm{OCH}_{2} \mathrm{CHC}(\mathrm{Me})_{2} ; \mathrm{R}_{2}=\mathrm{H} ; \mathrm{R}_{3}=\mathrm{H} ; \mathrm{R}_{4}=\mathrm{H}$ $45 \mathrm{R}_{1}=\mathrm{H} ; \mathrm{R}_{2}=\mathrm{OCH}_{2} \mathrm{CHC}(\mathrm{Me})_{2} ; \mathrm{R}_{3}=\mathrm{H} ; \mathrm{R}_{4}=\mathrm{H}$
$46 \mathrm{R}_{1}=\mathrm{OMe} ; \mathrm{R}_{2}=\mathrm{CH}_{2} \mathrm{CHC}(\mathrm{Me})_{2} \mathrm{R}_{3}=\mathrm{H} ; \mathrm{R}_{4}=\mathrm{H}$ $47 \mathrm{R}_{1}=\mathrm{H} ; \mathrm{R}_{2}=\mathrm{H} ; \mathrm{R}_{3}=\mathrm{CH}(\mathrm{Me})_{2} ; \mathrm{R}_{4}=\mathrm{OMe}$ $48 \mathrm{R}_{1}=\mathrm{H} ; \mathrm{R}_{2}=\mathrm{OCH}_{2} \mathrm{CH}(\mathrm{O}) \mathrm{C}(\mathrm{O})(\mathrm{Me})_{2} ; \mathrm{R}_{3}=\mathrm{H} ; \mathrm{R}_{4}=\mathrm{H}$ $49 \mathrm{R}_{1}=\mathrm{OC}(\mathrm{O}) \mathrm{Me} ; \mathrm{R}_{2}=\mathrm{OCH}_{2} \mathrm{CH}(\mathrm{O}) \mathrm{CH}(\mathrm{O})(\mathrm{Me})_{2} ; \mathrm{R}_{3}=\mathrm{H} ; \mathrm{R}_{4}=\mathrm{H}$ $50 \mathrm{R}_{1}=\mathrm{H} ; \mathrm{R}_{2}=\mathrm{OCH}_{2} \mathrm{C}(\mathrm{O}) \mathrm{CH}(\mathrm{Me})_{2} ; \mathrm{R}_{3}=\mathrm{H} ; \mathrm{R}_{4}=\mathrm{H}$ $55 \mathrm{R}_{1}=\mathrm{H}_{;} \mathrm{R}_{2}=\mathrm{OCH}_{2} \mathrm{CH}(\mathrm{OAC}) \mathrm{C}(\mathrm{OH})(\mathrm{Me})_{2} ; \mathrm{R}_{3}=\mathrm{H} ; \mathrm{R}_{4}=\mathrm{H}$ $59 \mathrm{R}_{1}=\mathrm{H}_{;} \mathrm{R}_{2}=\mathrm{OCH}_{2} \mathrm{CH}(\mathrm{OH}) \mathrm{C}(\mathrm{OMe})(\mathrm{Me})_{2} \mathrm{R}_{3}=\mathrm{H}_{;} \mathrm{R}_{4}=\mathrm{H}$ $60 \mathrm{R}_{1}=\mathrm{OCH}_{2} \mathrm{CH}(\mathrm{O}) \mathrm{C}(\mathrm{O})(\mathrm{Me})_{2} ; \mathrm{R}_{2}=\mathrm{H} ; \mathrm{R}_{3}=\mathrm{H}_{7} ; \mathrm{R}_{4}=\mathrm{H}$ $61 \mathrm{R}_{1}=\mathrm{OCH}_{2} \mathrm{CH}(\mathrm{OH}) \mathrm{C}(\mathrm{OH})(\mathrm{Me})_{2} ; \mathrm{R}_{2}=\mathrm{H} ; \mathrm{R}_{3}=\mathrm{H} ; \mathrm{R}_{4}=\mathrm{H}$ $\begin{array}{ll}62 \mathrm{R}_{1} & =\mathrm{OCH}_{2} \mathrm{CH}(\mathrm{OH}) \mathrm{C}(\mathrm{OMe})(\mathrm{Me})_{2} ; \mathrm{R}_{2}=\mathrm{H} ; \mathrm{R}_{3}=\mathrm{H} ; \mathrm{R}_{4}=\mathrm{H} \\ 63 \mathrm{R}_{1} & =\mathrm{H} ; \mathrm{R}_{2}=\mathrm{OCH}_{2} \mathrm{CH}(\mathrm{OH}) \mathrm{C}(\mathrm{Me})_{2} \mathrm{OGlu} ; \mathrm{R}_{3}=\mathrm{H} ; \mathrm{R}_{4}=\mathrm{H}\end{array}$ $66 \mathrm{R}_{1}=\mathrm{OCH}_{2} \mathrm{CH}\left(\mathrm{C}(\mathrm{OH})(\mathrm{Me})_{2}\right)(\mathrm{OC}(\mathrm{O}) \mathrm{Me}) ; \mathrm{R}_{2}=\mathrm{H} ; \mathrm{R}_{3}=\mathrm{H} ; \mathrm{R}_{4}=\mathrm{H}$ $68 \mathrm{R}_{1}=\mathrm{OMe} ; \mathrm{R}_{2}=\mathrm{OMe} ; \mathrm{R}_{3}=\mathrm{H} ; \mathrm{R}_{4}=\mathrm{H}$ $72 \mathrm{R}_{1}=\mathrm{OCH}_{2} \mathrm{CHC}(\mathrm{Me})_{2} ; \mathrm{R}_{2}=\mathrm{OMe} ; \mathrm{R}_{3}=\mathrm{H} ; \mathrm{R}_{4}=\mathrm{H}$ $73 \mathrm{R}_{1}=\mathrm{OCH}_{2} \mathrm{CH}(\mathrm{O}) \mathrm{C}(\mathrm{O})(\mathrm{Me})_{2} ; \mathrm{R}_{2}=\mathrm{H}_{3} \mathrm{R}_{3}=\mathrm{H} ; \mathrm{R}_{4}=\mathrm{H}$ $75 \mathrm{R}_{1}=\mathrm{H} ; \mathrm{R}_{2}=\mathrm{OCH}_{2} \mathrm{CH}(\mathrm{OAC}) \mathrm{C}(\mathrm{Me})_{2} \mathrm{OH} ; \mathrm{R}_{3}=\mathrm{H} ; \mathrm{R}_{4}=\mathrm{H}$
$76 \mathrm{R}_{1}=\mathrm{OCH}_{2} \mathrm{CHC}(\mathrm{Me})_{2} ; \mathrm{R}_{2}=\mathrm{H} ; \mathrm{R}_{3}=\mathrm{H} ; \mathrm{R}_{4}=\mathrm{H}$ $77 \mathrm{R}_{1}=\mathrm{H} ; \mathrm{R}_{2}=\mathrm{OCH}_{2} \mathrm{CH}(\mathrm{OH}) \mathrm{C}(\mathrm{Me})_{2} ; \mathrm{R}_{3}=\mathrm{H} ; \mathrm{R}_{4}=\mathrm{H}$ $80 \mathrm{R}_{1}=\mathrm{OCH}_{2} \mathrm{C}(\mathrm{O}) \mathrm{CH}(\mathrm{Me})_{2} ; \mathrm{R}_{2}=\mathrm{H} ; \mathrm{R}_{3}=\mathrm{H} ; \mathrm{R}_{4}=\mathrm{H}$ $86 \mathrm{R}_{1}=\mathrm{OCH}_{2} \mathrm{CH}_{2} \mathrm{C}\left(\mathrm{CH}_{2}\right)(\mathrm{Me}) ; \mathrm{R}_{2}=\mathrm{H} ; \mathrm{R}_{3}=\mathrm{H} ; \mathrm{R}_{4}=\mathrm{H}$ $90 \mathrm{R}_{1}=\mathrm{H} ; \mathrm{R}_{2}=\mathrm{OCH}_{2} \mathrm{CH}(\mathrm{OH}) \mathrm{C}(\mathrm{Me})_{2} \mathrm{OGlu}_{3} \mathrm{R}_{3}=\mathrm{H} ; \mathrm{R}_{4}=\mathrm{H}$
$91 \mathrm{R}_{1}=\mathrm{OCH}_{2} \mathrm{CH}(\mathrm{OH}) \mathrm{C}(\mathrm{Me})_{2} \mathrm{OGlu} ; \mathrm{R}_{2}=\mathrm{H} ; \mathrm{R}_{3}=\mathrm{H} ; \mathrm{R}_{4}=\mathrm{H}$ $92 \mathrm{R}_{1}=\mathrm{OCH}_{2} \mathrm{CH}(\mathrm{OH}) \mathrm{C}(\mathrm{Me})_{2} \mathrm{OC}(\mathrm{O}) \mathrm{C}(\mathrm{Me})(\mathrm{CH}(\mathrm{Me})) ; \mathrm{R}_{2}=\mathrm{H} ; \mathrm{R}_{3}=\mathrm{H} ; \mathrm{R}_{4}=\mathrm{H}$

C:

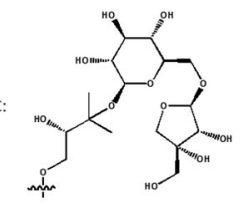

$57 \mathrm{R}_{1}=\mathrm{H} ; \mathrm{R}_{2}=\mathrm{C}$ $64 R_{1}=C ; R_{2}=H$

E:

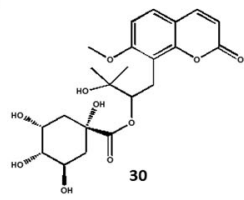

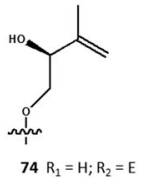

$74 R_{1}=H ; R_{2}=E$

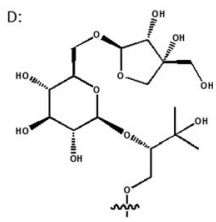

$58 R_{1}=H ; R_{2}=D$

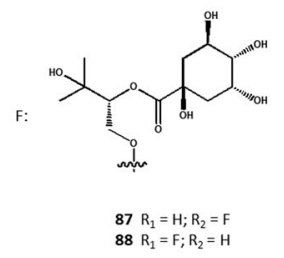

Fig. 1 Chemical structures of the compounds of Prangos spp.

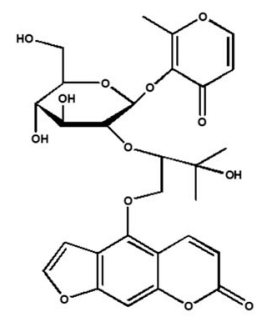

81

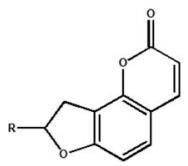

$94 \mathrm{R}=\mathrm{C}\left(\mathrm{CH}_{2}\right)(\mathrm{Me})$ $95 \mathrm{R}=\mathrm{C}(\mathrm{Me})_{2} \mathrm{OH}$
$96 \mathrm{R}=\mathrm{C}(\mathrm{Me})_{2} \mathrm{OGIC}$

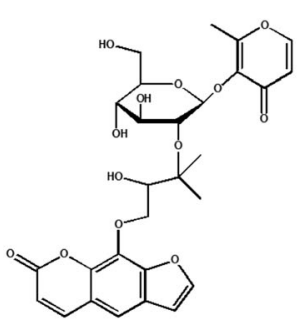

82

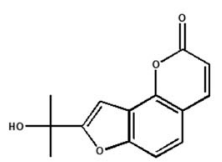

93

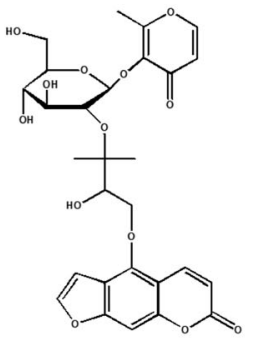

83

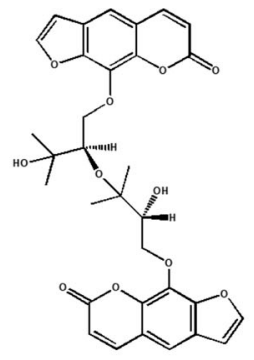

84

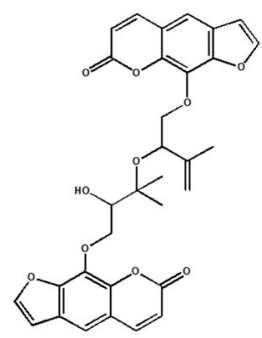

85

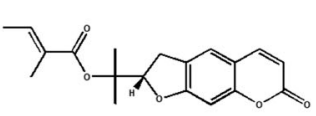

$43 \mathrm{R}=\mathrm{C}(\mathrm{Me})_{2} \mathrm{OC}(\mathrm{O}) \mathrm{C}(\mathrm{Me})(\mathrm{OH}) \mathrm{CH}(\mathrm{OH})(\mathrm{Me})$ $67 \mathrm{R}=\mathrm{C}(\mathrm{Me})_{2} \mathrm{OC}(\mathrm{O}) \mathrm{C}(\mathrm{Me}) \mathrm{CH}(\mathrm{Me})$ $69 \mathrm{R}=\mathrm{C}(\mathrm{Me})_{2} \mathrm{OH}$ $70 \mathrm{R}=\mathrm{C}(\mathrm{Me})_{2} \mathrm{OGlu}$
$71 \mathrm{R}=\mathrm{C}(\mathrm{Me})(\mathrm{OH}) \mathrm{CH}_{2} \mathrm{OH}$

79

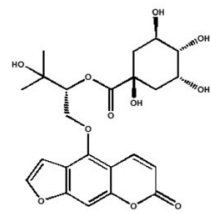

$78 \mathrm{R}=\mathrm{CH}(\mathrm{Me}) \mathrm{CH}_{2} \mathrm{OC}(\mathrm{O}) \mathrm{CHC}(\mathrm{Me})_{2}$

87

Fig. 1 continued

Springer 
<smiles></smiles>

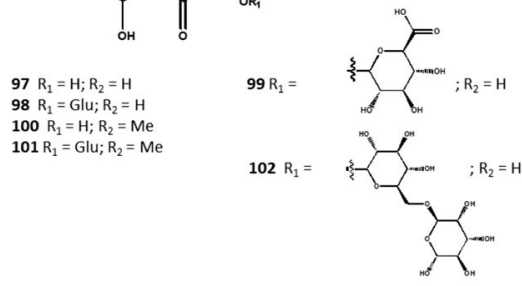<smiles>C=C1CCC(C)C2(C)CCC(C(C)C)[C@H](C)C12</smiles>

113

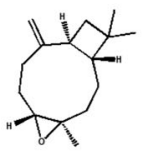

114<smiles>CC1=CC(C)(C)C2C(C)CCC2C1=O</smiles>

103<smiles>CCCc1ccc(C)c(C)c1C</smiles>

104<smiles>CCC1=CC(=O)C(C)=CC1(C)C</smiles>

$105 R=$ Glu<smiles>CCCC1CC(=O)C(C)=CC1(C)C</smiles>

107

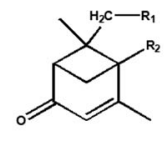

$108 \mathrm{R}_{1}=$ OGlu; $\mathrm{R}_{2}=\mathrm{H}$ $109 R_{1}=H ; R_{2}=$ OGlu<smiles>C=C1CCCC2C(C1C)C(C)(C)CCC2(C)C</smiles>

110<smiles>CC1CCC2C(C(C)(C)C)CCCC(C)(C)C12</smiles>

111<smiles>C=C1C=C(C)C2CC(=C(C)C)CCC2(C)C1</smiles>

112

Fig. 1 continued<smiles>CC1(C)CCCC23CCC4C(C)(C)CCC4(CCC12)C3</smiles>

115<smiles>CCC1C=C(C(C)=O)C(C)(C)C=C1C</smiles>

116<smiles>C=C(C)C1=CC=C(C)C(OC)C1(C)C</smiles>

117<smiles>Cc1occc(=O)c1O</smiles>

$119 \mathrm{R}=\mathrm{H}$ $120 \mathrm{R}=\mathrm{Glu}$

$122 \mathrm{R}=6-\mathrm{O}$-feruloyl-Glu $123 \mathrm{R}=6$-O-cis-feruloyl-Glu $124 R=6$-O-isovaleryl-Glu $125 \mathrm{R}=6$-O-caffeoyl-Glu

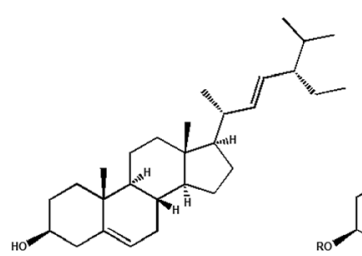

129<smiles>CCC1OC(COc2c(C)occc2=O)C(C)[C@@H](C)[C@H]1O</smiles>

121<smiles>C[C@H]1CC(C)(C)C2=CC(=O)OC2(C)C1</smiles>

126<smiles>O=C(O)/C=C/c1ccc(O)c(O)c1</smiles><smiles>C=C(C)C1CC(C)C(C)C(CCCCC)C1C</smiles><smiles>CC(C)OC1NC(C)C(C)[C@H](C)C1O</smiles>

132

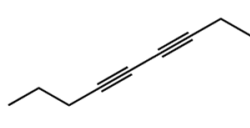

133

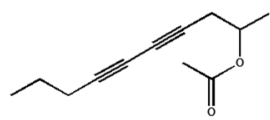

134

Fig. 1 continued

Linear furocoumarins

Psoralen (31) was isolated and identified from various extracts of P. lipskyi (Danchul et al. 1975a), P. acaulis
(Kuznetsova et al. 1979), P. quasiperforata (Danchul et al. 1975b), P. tschimganica (Shikishima et al. 2001b), P. ferulacea (Shokoohinia et al. 2014), and $P$. hulusii (Tan et al. 2017). A psoralen derivative called 
8-geranyloxy psoralen (32) was also isolated from $n$ hexane extract of the root part of $P$. uloptera (Razavi et al. 2009a).

In a study carried out by Shikishima et al. (2001a), the $n$-butanol extract from the aerial parts of $P$. tschimganica was fractionated to yield saxalin (33), ( \pm )-8-(3-chloro-2-hydroxyl-3-methylbutoxy)-psoralen (syn. isosaxalin) (34), xanthotoxin (36), xanthotoxol (37), bergapten (38), isogosferol (42), imperatorin (44), isoimperatorin (45), oxypeucedanin hydrate (52), heraclenol (61), tert- $O$-methyl heraclenol (62), pabulenol (74), and pabularinone (80) (Shikishima et al. 2001b).

Different parts including aerial parts and roots of $P$. ferulacea have been studied for their phytochemical contents. From various extracts (chloroform, methanolic, acetone) 8-[2-(3-methylbutyroxy)-3-hydroxyl-3-methylbutoxylpsoralen (35), gosferol (41), oxypeucedanin (48), oxypeucedanin methanolate (59), heraclenin (60), isopimpinellin (68), phellopterin (72), pranferol (77), feruliden (86), and [3-hydroxy-2methyl-4-(7-oxofuro[3,2 g]chromen-9-yl) oxybutan2-yl] (Z)-2-methylbut-2-enoate (92) were isolated (Kuznetsova et al. 1966; Abyshev 1974; Shokoohinia et al. 2014; Gholivand et al. 2015; Abbas-Mohammadi et al. 2018).

Ulubelen et al. (1995) isolated bergaptol (39), $n$ butyl bergaptol (40), 8-acetyloxypeucedanin (49), and prangenin (73) from chloroform extract of $P$. platychlaena (Ulubelen et al. 1995).

Furthermore, various researchers have been investigated the secondary metabolite profile of $P$. pabularia. The linear furocoumarins allo-imperatorin methyl ether (46), oxypeucedanin hydrate $2^{\prime}-O$ monoacetate $(\mathbf{5 3})$, oxypeucedanin hydrate monoacetate (55), heraclenol 3'-methyl ester (66), 8-((3,3dimethyloxiran-2-yl) methyl)-7-methoxy-2H-chromen-2-one (syn. merangin) (75), and 4-((2-hydroxy3-methylbut-3-en-1-yl) oxy)-7H-furo[3,2-g] chromen-7-one (76) were isolated from the plant (Koul et al. 1979; Tada et al. 2002; Farooq et al. 2014a).

Peucedanin (47) and isooxypeucedanin (50) were isolated and identified from $P$. biebersteinii, whereas aviprin (89) from P. uloptera (Abyshev and Brodskii 1974; Geidarov and Serkerov 2016; Heydarov and Serkerov 2017).
Linear dihydro-furocoumarins

From the methanolic extract of $P$. ferulacea roots, a new natural product, lindiol (43) have been isolated (Abyshev 1974). Sprengelianin (67) was isolated as a dihydro-furocoumarin derivative from $n$-hexane extract of aerial parts of $P$. ferulacea (Abbas-Mohammadi et al. 2018). Furthermore, marmesine (69) and its dehydrated glycosylated form marmesinine (70) were found in several Prangos species: P. ferulacea (Abbas-Mohammadi et al. 2018), P. latiloba (Serkerov et al. 1976), P. quasiperforata (Danchul et al. 1975a), P. tschimganica (Shikishima et al. 2001b), P. lipskyi (Danchul et al. 1975a) and P. biebersteinii (Geidarov and Serkerov 2016).

Prandiol (71) was isolated for the first time from methanolic extract of the roots of P. biebersteinii (Abyshev and Brodskii 1974). Diverse separation techniques were utilized to isolate pranchimgin (78) and deltoin (79) from different Prangos species as dihydro-furocoumarin compounds (Danchul et al. 1975a; Serkerov et al. 1976; Kuznetsova et al. 1979; Eshbakova et al. 2006; Razavi et al. 2008b).

Glycosylated furocoumarins

Several glycosylated furocoumarins were detected in three Prangos species. From $P$. pabularia, oxypeucedanin hydrate $3^{\prime}-O$ - $\beta$-D-glucopyranoside (54), oxypeucedanin hydrate $3^{\prime}-O$ - $\beta$-D-glucopyranoside $(\mathbf{5 6})$, heraclenol $3^{\prime}-O-\beta$-D-glucopyranoside $(63), 3^{\prime \prime}-O-(\beta$-Dglucopyranosyl)-heraclenol (65), aviprin- $3^{\prime \prime}$ - $O$-D-glucopyranoside (90), and (-)9-[3-( $\beta$-D-glucopyranosyloxy)-2 hydroxy-3-methyl butoxy]-7H furo [3,2-g] [1]benzopyran-7-one (syn. komaline $2^{\prime}$ - $\beta$-D-glucopyranoside) (91) were isolated (Koul et al. 1979; Tada et al. 2002; Farooq et al. 2014a; Numonov et al. 2018).

Two new compounds 3 " $-O$-[ $\beta$-D-apiofuranosyl$(1 \rightarrow 6)$ - $\beta$-D-glucopyranosyl]-oxypeucedanin hydrate (57) and $2^{\prime \prime}-O$-[ $\beta$-D-apiofuranosyl- $(1 \rightarrow 6)$ - $\beta$-D-glucopyranosyl]-oxypeucedanin hydrate $(\mathbf{5 8})$, along with $3^{\prime \prime}$ - $O$-[ $\beta$-D-apiofuranosyl-( $\left.1 \rightarrow 6\right)$ - $\beta$-D-glucopyranosyl]-heraclenol (64) and aviprin-3' $-O$-D-glucopyranoside (90) were isolated as glycosylated linear furocoumarins from the methanolic extract of $P$. uloptera roots (Razavi et al. 2008a; Zahri et al. 2012).

Shikishima et al. (2001a) isolated two new glycosylated furocoumarins, tschimganic ester B (87) and 
tschimganic ester $\mathrm{C}(\mathbf{8 8})$ from methanolic extract of $P$. tschimganica aerial parts (Shikishima et al. 2001b).

Angular furocoumarins

From the $n$-hexane extract of $P$. ferulacea, oroselol (93) was obtained (Abbas-Mohammadi et al. 2018). Majurin (94) was isolated from the $n$-hexane extract of $P$. pabularia stems (Tada et al. 2002). Columbianetin (95) and columbianetin- $O$ - $\beta$-D-glucopyranoside (96) were isolated and identified from $P$. tschimganica (Shikishima et al. 2001b).

\section{Condensed furocoumarin derivatives}

The new furocoumarin derivatives pabularin A (81), pabularin B (82), and pabularin C (83) were obtained from the EtOAc extract of $P$. pabularia stems. A known compound rivurobirin $\mathrm{E}$ (84) was also isolated from the same plant extract (Tada et al. 2002). Rivulobirin A (85) was isolated from $n$-hexane extract of P. ferulacea (Abbas-Mohammadi et al. 2018).

\section{Flavonoids}

Two flavonoid aglycones: quercetin (97) and isorhamnetin (100) were isolated from $P$. ferulacea. Their glycosydes, quercetin-3-O-glucoside (98), and isorhamnetin-3-O- $\beta$-D-glucopyranoside (101), along with querciturone (99) were obtained from P. ferulacea (Razavi et al. 2009c; Mouri et al. 2014; Delnavazi et al. 2017; Abbas-Mohammadi et al. 2018). Rutin (102) was also reported as one of the components of $P$. denticulata and $P$. heyniae (OkeAltuntas et al. 2015).

Terpenoids

From the methanolic extract of the aerial parts of $P$. tschimganica, two new monoterpenes, tschimganical A (103) and 1,1,5-trimethyl-2-hydroxymethyl-(2,5)cyclohexadien-(4)-one (106), two known monoterpenes 1,1,5-trimethyl-2-formyl-4-methoxyl-(2,5)-cyclohexadiene (118) and 1,1,5-trimethyl-2-formyl-6-methoxyl(2,4)-cyclohexadiene (119), along with five new monoterpene glycosides including 2,3,4-trimethylbenzylalcohol- $O$ - $\beta$-D-glucopyranoside (106), 1,1,5-trimethyl-2-hydroxymethyl-(2,5)-cyclohexadien-(4)-one$O$ - $\beta$-D-glucopyranoside (105), 1,1,5-trimethyl-2- hydroxymethyl-5-cyclohexadien-(4)-one-7- $O$ - $\beta$-D-glucopyranoside (107), vervenone-8- $O-\beta$-D-glucopyranoside (108), and vervenone-5- $O$ - $\beta$-D-glucopyranoside (109) were isolated (Shikishima et al. 2001a). In this study, the presence of further terpenoids, namely spathulenol (110), globulol (111), 1 $\beta, 6 \alpha$-dihydroxyeudesm-4(15)-ene (syn. voleneol) (113), and (-)caryophyllene- $\beta$-oxide (114) was detected (Shikishima et al. 2001a).

From the EO of $P$. heyniae a new eudesmane type sesquiterpene, 3,7(11)-eudesmadien-2-one (110) was isolated (Ozek et al. 2018).

The diterpenoid kauranol (115) was obtained and identified from P. pabularia (Tada et al. 2002).

A new terpenoid (118) was also isolated from $P$. haussknechtii aerial parts by using diverse range of chromatographic techniques (Dissanayake et al. 2017).

$\gamma$-Pyrones

From $P$. tschimganica the $\gamma$-pyrone aglycone maltol (119), and five glycosides including maltol- $\beta$-D-glucopyranoside (120), 3-hydroxyl-2-methyl-4-H-pyran4-one-3-O-(6)- $\beta$-D-glucopyranoside (122), 3-hydroxyl-2-methyl-4-H-pyran-4-one-3-O-(6-O-cis-feruloyl)- $\beta$-D-glucopyranoside (123), 3-hydroxyl-2methyl-4-H-pyran-4-one-3-O-(6-O-cis-isovaleryl)- $\beta$ D-glucopyranoside (124), and 3-hydroxyl-2-methyl-4H-pyran-4-one-3-O-(6-O-cis-caffeoyl)- $\beta$-D-glucopyranoside (125) were isolated and identified (Shikishima et al. 2001a).

A new $\gamma$-pyrone derivative, maltol-(6- $O$-acetyl)- $\beta$ D-glucopyranoside (121) was also isolated for the first time from EtOAc extract of $P$. pabularia stem (Tada et al. 2002).

\section{Other compounds}

Beside the above-listed main constituents of the Prangos genus, a carotenoid named loliolide (126) from $P$. pabularia, caffeic acid glucosyl ester (127) from $P$. ferulacea, and chlorogenic acid (128) from $P$. denticulata and $P$. heyniae were reported (Tada et al. 2002; Oke-Altuntas et al. 2015; Delnavazi et al. 2017). The ubiquitous phytosterols stigmasterol (129) and $\beta$ sitosterol (130) were identified from $P$. hulusii roots, and $\beta$-sitosterol- $\beta$-D-glucopyranoside (131) from $P$. pabularia stems (Tada et al. 2002; Tan et al. 2017). 


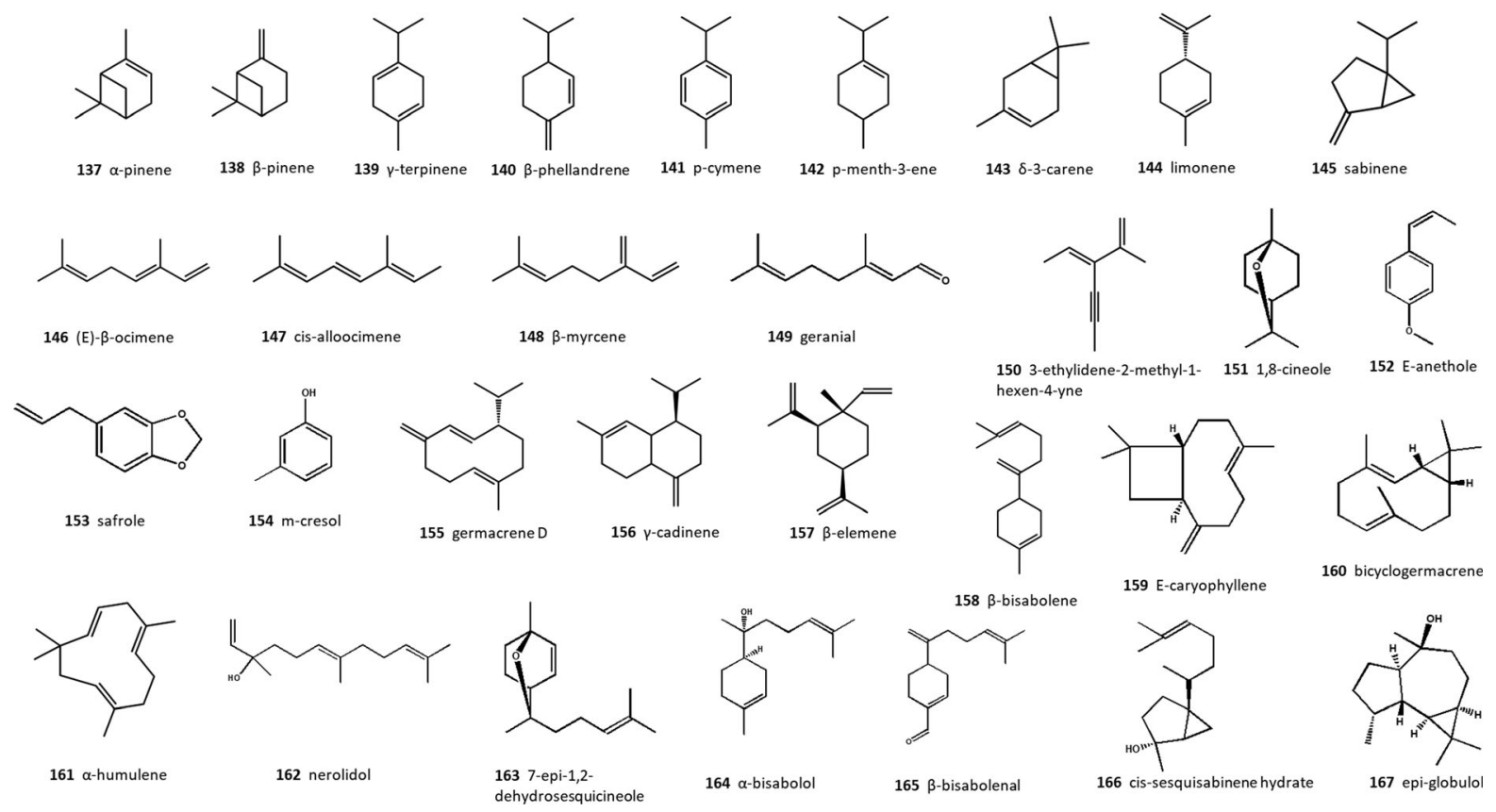

Fig. 2 Major essential oil constituents of Prangos spp.

Three polyacetylene compounds were also identified from the genus, namely: $1-O$-isopropyl- $\beta$-D-glucopyranoside (132) from $P$. pabularia, 3,5-nonadiyne (133) from $P$. ferulacea, and nona-(2S)-3,5-diyn-2-yl acetate (134) from P. platychlaena (Tada et al. 2002; Dokovic et al. 2004; Tabanca et al. 2018).

2-(4-Hydroxyphenyl) ethyl triacontanoate (135) was also isolated from $n$-hexane extract of aerial parts of P. ferulacea (Abbas-Mohammadi et al. 2018). An amino acid derivative (136) was isolated from the methanolic extract obtained from the aerial parts of $P$. haussknechtii (Dissanayake et al. 2017).

Essential oils

Various parts of Prangos genus including fruits, seeds, and flowers at different growth stages were subjected to analyse the compositions of their EOs (Table S4). The roots of $P$. denticulata and immature seeds of $P$. ferulace a at flowering stage possessed the highest EO contents with $3.2 \%(\mathrm{v} / \mathrm{w})$ and $3.0 \%(\mathrm{w} / \mathrm{w})$, respectively (Kilic et al. 2010; Bagherifar et al. 2019). The chemical structures of the main EO components are given in Fig. 2. As demonstrated in Table S4, monoterpene hydrocarbons were the major EO constituents. Among them, $\alpha$-pinene (137), $\beta$-pinene
(138), $\gamma$-terpinene (139), $\beta$-phellandrene (140), and $p$-cymene (141) were characterized as the main terpenoids.

Although monoterpenes were the most abundant volatile constituents, sesquiterpene hydrocarbons were further detected as significant fragrance components of the Prangos genus. In this terpenoid class, the genus was rich in germacrene $D(\mathbf{1 5 5}), \gamma$-cadinene (156), $\beta$-elemene (157), and $\beta$-bisabolene (158) (Fig. 2).

\section{Conclusions and prospective}

Prangos species have been extensively used as food and medicine in Asia. Prangos species have been the subject of intense phytochemical examination in the past few decades. From the 30 Prangos species existing worldwide, 15 and 17 species have been investigated for non-volatile components and EO compositions, respectively. Furthermore, biological activities of 14 plant species have been evaluated. In these studies, crude extracts, EOs, and pure compounds isolated from Prangos species have been tested. 
Phytochemical investigations of the genus revealed that coumarins, flavonoids and terpenoids are the major components of the plants. Coumarin derivatives, including aglycones and glycosylated simple coumarins, aglycones and glycosylated linear and angular furocoumarins, and condensed furocoumarins are the main constituents of this genus. There are no quantitative data on the non-volatile secondary metabolites, and their occurrence in different plant parts has not been studied extensively. Different plant parts of this genus are fragrant and produce EO with remarkable yield. Monoterpene hydrocarbons, especially $\alpha$ - and $\beta$-pinenes, $\gamma$-terpinene, (E)- $\beta$-ocimene, and $\delta$-3-carene have been identified as the major volatile oil components.

Since coumarins have a wide range of pharmacological effects (e.g. anti-neurodegenerative, antiviral, antimicrobial, antioxidant, antidiabetic, anti-inflammatory, and anticancer activities), the genus is a promising source of new bioactive compounds. However, considering the toxic effects of certain furocoumarins, including their cytotoxic and carcinogenic effects (Mullen et al. 1984), there is a need for further studies to support the safe use of Prangos species or their extracts. All the phytochemical studies reporting furocoumarins were preparative experiments and there are no quantitative data on the occurrence of furocoumarins in different species and plant parts. Moreover, the toxicological profiles of Prangos species is unknown, since no scientific studies focused on this aspect. The majority of the studies reported antimicrobial and antioxidant effects, and with one exception all the experiments were carried out in vitro.

Further pharmacological studies, including in vivo studies would be indispensable in determining and assessing the pharmacological potential of the isolated compounds and the species of the genus. The available experimental evidence does not support the rationale folk medicinal use of Prangos species. Although the antimicrobial activities may explain some of the uses, no human studies were carried out to assess efficacy and safety. The application as spice might be related to the essential oil and coumarin content of the species; however, the safety of these food is yet to be studied.

Acknowledgements Open access funding provided by University of Szeged (SZTE). Financial support from the Economic Development and Innovation Operative Programme GINOP-2.3.2-15-2016-00012 is gratefully acknowledged.

\section{Compliance with ethical standards}

Conflict of interest The authors declare that they have no conflict of interest.

Open Access This article is licensed under a Creative Commons Attribution 4.0 International License, which permits use, sharing, adaptation, distribution and reproduction in any medium or format, as long as you give appropriate credit to the original author(s) and the source, provide a link to the Creative Commons licence, and indicate if changes were made. The images or other third party material in this article are included in the article's Creative Commons licence, unless indicated otherwise in a credit line to the material. If material is not included in the article's Creative Commons licence and your intended use is not permitted by statutory regulation or exceeds the permitted use, you will need to obtain permission directly from the copyright holder. To view a copy of this licence, visit http://creativecommons.org/licenses/by/4.0/.

\section{References}

Abbas-Mohammadi M, Farimani MM, Salehi P et al (2018) Acetylcholinesterase-inhibitory activity of Iranian plants: combined HPLC/bioassay-guided fractionation, molecular networking and docking strategies for the dereplication of active compounds. J Pharm Biomed Anal 158:471-479. https://doi.org/10.1016/j.jpba.2018.06.026

Abolghasemi MM, Piryaei M (2012) Fast determination of Prangos uloptera essential oil by nanoporous silica-polypyrrole SPME fiber. Chemija 23:244-249

Abyshev AZ (1974) Structure of some components of the roots of Prangos ferulacea. Chem Nat Compd 10:581-585. https://doi.org/10.1007/BF00567845

Abyshev AN, Brodskii IV (1974) Prandiol: a new dihydrofurocoumarin from the roots of Prangos biebersteinii. Chem Nat Compd 10:586-588. https://doi.org/10.1007/ BF00567846

Ahmed J, Guvenc A, Kucukboyaci N et al (2011) Total phenolic contents and antioxidant activities of Prangos Lindl. (Umbelliferae) species growing in Konya province (Turkey). Turk J Biol 35:353-360. https://doi.org/10.3906/biy0809-23

Akbari MT, Esmaeili A, Zarea AH et al (2010) Chemical composition and antibacterial activity of essential oil from leaves, stems and flowers of Prangos ferulacea (L.) Lindl. grown in Iran. Bulg Chem Commun 42:36-39

Akhlaghi $\mathrm{H}$ (2015) GC/MS analysis of the essential oils from aerial parts of Prangos latiloba Korov. collected in Northeast Iran. Nat Prod Chem Res 3:1-4. https://doi.org/ 10.4172/2329-6836.1000158

Akhlaghi SH, Hashemi P (2005) Chemical compositions of the essential oils of stems, leaves, and roots of Prangos latiloba. Chem Nat Compd 41:542-544

Akhlaghi H, Nekoeiz M, Mohammadhosseini M, Motavalizadehkakhky A (2012) Chemical composition of the volatile oils from the flowers, stems and leaves of Prangos 
latiloba korov. using the head space solid phase microextraction method prior to analysis by gas chromatographymass spectrometry. J Essent Oil-Bearing Plants 15:328-335. https://doi.org/10.1080/0972060X.2012. 10644055

Altuntas FO, Aslim B, Duman H (2011) Inhibitory effect of Prangos meliocarpoides Boiss var. meliocarpoides on lipid peroxidation and hydrogen peroxide-induced cell damage. Curr Opin Biotechnol 22:S99-S100. https://doi.org/10. 1016/j.copbio.2011.05.313

Bagherifar S, Sourestani MM, Zolfaghari M et al (2019) Chemodiversity of volatile oil contents of various parts of 10 iranian Prangos ferulacea accessions, with analysis of antiradical potential. Nat Prod Commun. https://doi.org/10. 1177/1934578X19851985

Bahadori MB, Zengin G, Bahadori S et al (2017a) Chemical composition of essential oil, antioxidant, antidiabetic, antiobesity, and neuroprotective properties of Prangos gaubae. Nat Prod Commun 12:1934578X1701201. https://doi.org/ 10.1177/1934578X1701201233

Bahadori MB, Zengin G, Bahadori S et al (2017b) Chemical composition of essential oil, antioxidant, antidiabetic, antiobesity, and neuroprotective properties of Prangos gaubae. Nat Prod Commun 12:1945-1948

Banday JA, Bhat GM, Mir FA et al (2013a) Heraclenin: a potential optoelectronic device material from Prangos pabularia. J Electron Mater 42:2498-2503. https://doi.org/ 10.1007/s11664-013-2596-x

Banday JA, Mir FA, Kanth AH, Bhat GM (2013b) Structural and optical properties of Heraclenin; a bio-organic molecule from Prangos pabularia. Optik (Stuttg) 124:4655-4658. https://doi.org/10.1016/j.ijleo.2013.01. 114

Banday JA, Mir FA, Qurishi MA et al (2013c) Isolation, structural, spectral, and thermal studies of imperatorin micro-crystals from Prangos pabularia. J Therm Anal Calorim 112:1165-1170. https://doi.org/10.1007/s10973012-2683-X

Baser KHC, Ermin N, Adigüzel N, Aytaç Z (1996) Composition of the essential oil of Prangos ferulacea (L.) Lindl. J Essent Oil Res 8:297-298. https://doi.org/10.1080/10412905. 1996.9700617

Baser KHC, Demirci B, Demirci F et al (2000a) A new bisabolene derivative from the essential oil of Prangos uechtritzii fruits. Planta Med 66:674-677. https://doi.org/ 10.1055/s-2000-8627

Baser KHC, Ozek T, Demirci B, Duman H (2000b) Composition of the essential oil of Prangos heyniae H. Duman et M. F. Watson, a new endemic from Turkey. Flavour Fragr J 15:47-49. https://doi.org/10.1002/(SICI)1099-1026(200001/ 02)15:1\%3c47:AID-FFJ869\%3e3.0.CO;2-9

Bazdar M, Sadeghi H (2018) Antioxidant activity of Trifolium resupinatum $\mathrm{L}$. exposed to different extracts from leaves, flowers and shoots of Prangos ferulacea. Span J Agric Res 15:e0303. https://doi.org/10.5424/sjar/2017154-10779

Bazdar M, Sadeghi H, Hosseini S (2018) Evaluation of oil profiles, total phenols and phenolic compounds in Prangos ferulacea leaves and flowers and their effects on antioxidant activities. Biocatal Agric Biotechnol 14:418-423. https://doi.org/10.1016/j.bcab.2018.04.009
Blok C, Baumgarten A, Baas R et al (2019) Analytical methods used with soilless substrates. In: Soilless culture, Elsevier, Amsterdam, pp 509-564

Brusotti G, Ibrahim MF, Dentamaro A et al (2013) Chemical composition and antimicrobial activity of the volatile fractions from leaves and flowers of the wild iraqi kurdish plant Prangos peucedanifolia FENZL. Chem Biodivers 10:274-280. https://doi.org/10.1002/cbdv.201200202

Çelik SE, Özyürek M, Altun M et al (2008) Antioxidant capacities of herbal plants used in the manufacture of van herby cheese: 'Otlu Peynir'. Int J Food Prop 11:747-761. https://doi.org/10.1080/10942910701594210

Cesur C, Senkal Cosge B, Yaman C et al (2017) Antioxidant activity of fruit extracts of Prangos ferulacea (L.) Lindl. from Turkey. Igdir Univ J Inst Sci Technol 7:249-256

Çoruh N, Celep AGS, Özgökçe F (2007) Antioxidant properties of Prangos ferulacea (L.) Lindl., Chaerophyllum macropodum Boiss. and Heracleum persicum Desf. from Apiaceae family used as food in Eastern Anatolia and their inhibitory effects on glutathione-S-transferase. Food Chem 100:1237-1242. https://doi.org/10.1016/j.foodchem.2005. 12.006

Dagdelen S, Bilenler T, Durmaz G et al (2014) Volatile composition, antioxidant and antimicrobial activities of herbal plants used in the manufacture of van herby (otlu) cheese. J Food Process Preserv 38:1716-1725. https://doi.org/10. 1111/jfpp. 12134

Damyeh MS, Niakousari M, Saharkhiz MJ (2016) Ultrasound pretreatment impact on Prangos ferulacea Lindl. and $\mathrm{Sa}$ tureja macrosiphonia Bornm. essential oil extraction and comparing their physicochemical and biological properties. Ind Crops Prod 87:105-115. https://doi.org/10.1016/j. indcrop.2016.04.025

Danchul TY, Kuz'mina LV, Kuznetsova GA (1975a) Coumarins from the roots of Prangos lipsky 2-3

Danchul TY, Kuz'mina LV, Kuznetsova GA (1975b) Coumarins from the roots of Prangos lipskyi. Chem Nat Compd 11:256-257. https://doi.org/10.1007/BF00570686

Delnavazi MR, Soleimani M, Hadjiakhoondi A, Yassa N (2017) Isolation of phenolic derivatives and essential oil analysis of Prangos ferulacea (L.) lindl. aerial parts. Iran J Pharm Res 16:207-215

Dissanayake AA, Ameen BAH, Nair MG (2017) Lipid peroxidation and cyclooxygenase enzyme inhibitory compounds from Prangos haussknechtii. J Nat Prod 80:2472-2477. https://doi.org/10.1021/acs.jnatprod.7b00322

Dokovic DD, Bulatovic VM, Bozic BD et al (2004) 3,5-Nonadiyne isolated from the rhizome of Cachrys ferulacea inhibits endogenous nitric oxide release by rat peritoneal macrophages. Chem Pharm Bull (Tokyo) 52:853-854. https://doi.org/10.1248/cpb.52.853

Durmaz H, Sagun E, Tarakci Z, Ozgokce F (2006) Antibacterial activities of Allium vineale, Chaerophyllum macropodum and Prangos ferulacea. Afr J Biotechnol 5:1795-1798

Eshbakova KA, Saidkhodzhaev AI, Baser KHC et al (2006) Furocoumarins from Prangos ferulacea. Chem Nat Compd 42:102-103. https://doi.org/10.1007/s10600-006-0047-0

Farooq S, Shakeel-u-Rehman DN et al (2014a) Isolation, cytotoxicity evaluation and HPLC-quantification of the chemical constituents from Prangos pabularia. PLoS ONE. https://doi.org/10.1371/journal.pone.0108713 
Farooq S, Shakeel-u-Rehman DN et al (2014b) Isolation, cytotoxicity evaluation and HPLC-quantification of the chemical constituents from Prangos pabularia. PLoS ONE 9:e108713. https://doi.org/10.1371/journal.pone.0108713

Farooq S, Hussain A, Qurishi MA et al (2018) Synthesis and biological evaluation of novel triazoles linked 7-hydroxycoumarin as potent cytotoxic agents. Anticancer Agents Med Chem 18:1531-1539. https://doi.org/10.2174/ 1871520618666171229222956

Geidarov IG, Serkerov SV (2016) Coumarins from roots of Prangos biebersteinii. Chem Nat Compd 52:700-701. https://doi.org/10.1007/s10600-016-1746-9

Ghasemian M, Owlia S, Owlia MB (2016) Review of anti-inflammatory herbal medicines. Adv Pharmacol Sci 2016:1-11. https://doi.org/10.1155/2016/9130979

Gheisari HR, Habibi H, Khadem A et al (2016) Comparison of antimicrobial activity of Cichorium intybus, Dorema aucheri and Prangos ferulacea extracts against some food borne pathogens. Int J Pharm Res Allied Sci 5:80-84

Gholivand MB, Piryaei M, Abolghasemi MM, Papzan A (2013) Comparison of microwave-assisted headspace single-drop microextraction (MA-HS-SDME) with hydrodistillation for the determination of volatile compounds from Prangos uloptera. J Essent Oil Res 25:49-54. https://doi.org/10. 1080/10412905.2012.747267

Gholivand MB, Yamini Y, Dayeni M, Shokoohinia Y (2015) The influence of the extraction mode on three coumarin compounds yield from Prangos ferulacea (L.) Lindl roots. J Iran Chem Soc 12:707-714. https://doi.org/10.1007/ s13738-014-0529-0

Hayta Ş (2018) Essential oil composition of the fruit of Prangos uloptera (Apiaceae) DC. from Turkey. Chem J 5:1-5

Heydarov IH, Serkerov SV (2017) Study of biologically active compounds of the roots of Prangos biebersteinii Karjag. Proc ANAS. Biol Med Sci 72:57-61

Kafash-Farkhad N, Asadi-Samani M, Rafieian-Kopaei M (2013) A review on phytochemistry and pharmacological effects of Prangos ferulacea (L.) Lindl. Life Sci J 10:360-367. https://doi.org/10.13040/IJPSR.0975-8232.4(12).4531-36

Kazerooni T, Mousavizadeh K (2005) Effect of Prangos ferulacea on abortion on pregnant rats. Fertil Steril 84:S168S169. https://doi.org/10.1016/j.fertnstert.2005.07.417

Kazerooni T, Mousavizadeh K, Abdollahee A et al (2006) Abortifacient effect of Prangos ferulacia on pregnant rats. Contraception 73:554-556. https://doi.org/10.1016/j. contraception.2005.11.001

Khoury M, El Beyrouthy M, Eparvier V et al (2018) Chemical diversity and antimicrobial activity of the essential oils of four Apiaceae species growing wild in Lebanon. J Essent Oil Res 30:25-31. https://doi.org/10.1080/10412905.2017. 1372314

Kilic CS, Coskun M, Duman H et al (2010) Comparison of the essential oils from fruits and roots of Prangos denticulata Fisch et Mey. Growing in Turkey. J Essent Oil Res 22:170-173

Kiliç Ö, Bengü AS, Özdemir FA, Çelik S (2017) Essential oil composition of two Prangos lindl (Apiaceae) species from Turkey. Prog Nutr 19:69-74. https://doi.org/10.23751/pn. v19i1-S.5332

Kontogiorgis C, Hadjipavlou-Litina D (2003) Biological evaluation of several coumarin derivatives designed as possible anti- inflammatory/antioxidant agents. J Enzyme Inhib Med Chem 18:63-69. https://doi.org/10.1080/1475636031000069291

Koul SK, Dhar KL, Thakur RS (1979) A new coumarin glucoside from Prangos pabularia. Phytochemistry 18:1762-1763. https://doi.org/10.1016/0031-9422(79)80213-7

Kuznetsova GA, Abyshev AZ, Perelson ME et al (1966) A new coumarin, pranferol, from the roots of Prangos ferulacea. Khimiya Prir Soedin 2:310-315

Kuznetsova GA, Danchul TY, Sokolova EA, Kuzmina LV (1979) Coumarins from the roots and epigealmass of Prangos acaulis. Khimiya Prir Soedin 6:848-849

Loizzo MR, Saab AM, Tundis R et al (2008a) In vitro inhibitory activities of plants used in Lebanon traditional medicine against angiotensin converting enzyme (ACE) and digestive enzymes related to diabetes. J Ethnopharmacol 119:109-116. https://doi.org/10.1016/j.jep.2008.06.003

Loizzo MR, Tundis R, Menichini F et al (2008b) Antiproliferative effects of essential oils and their major constituents in human renal adenocarcinoma and amelanotic melanoma cells. Cell Prolif 41:1002-1012. https://doi.org/10.1111/j. 1365-2184.2008.00561.x

Lyskov DF, Degtjareva GV, Samigullin TH, Pimenov MG (2017) The revision of Prangos subsections Koelzella and Fedtschenkoana (Apiaceae) with some notes to phylogeny and biogeography of the genus: molecular and morphological evidences. Plant Syst Evol 303:815-826. https:// doi.org/10.1007/s00606-017-1412-0

Mamadalieva NZ, Abdullaeva NS, Rosenau T et al (2018) Composition of essential oils from four Apiaceae and Asteraceae species growing in Uzbekistan. Nat Prod Res 32:1118-1122. https://doi.org/10.1080/14786419.2017. 1375928

Masoudi S, Eghbali H, Abadi VK (2016) Volatile constituents of the aerial parts of Ferulago subvelutina Rech. f., Ferulago stellata Boiss., leaves and flowers of Prangos ferulacea (L.) Lindle. and leaves of Ferula ovina (Boiss.) Boiss. four umbelliferae herbs from Iran. J Essent Oil Bear Plants 19:592-605. https://doi.org/10.1080/0972060X.2014.935031

Mavi A, Terzi Z, Özgen U et al (2004) Antioxidant properties of some medicinal plants: prangos ferulacea (Apiaceae), Sedum sempervivoides (Crassulaceae), Malva neglecta (Malvaceae), Cruciata taurica (Rubiaceae), Rosa pimpinellifolia (Rosaceae), Galium verum subsp. verum (Rubiaceae). Urtica Biol Pharm Bull 27:702-705. https:// doi.org/10.1248/bpb.27.702

Mazloomifar H, Bigdeli M, Saber-Tehrani M et al (2004) Essential oil of Prangos uloptera dc. from Iran. J Essent Oil Res 16:415-416. https://doi.org/10.1080/10412905.2004. 9698758

Melough MM, Cho E, Chun OK (2018) Furocoumarins: a review of biochemical activities, dietary sources and intake, and potential health risks. Food Chem Toxicol 113:99-107

Meshkatalsadat MH, Mirzaei HH (2007) Chemical compositions of the essential oils of stems, leaves and flowers of Prangos acaulis (Dc) Bornm. Pak J Biol Sci 10:2775-2777. https://doi.org/10.3923/pjbs.2007.2775. 2777

Meshkatalsadat MH, Bamoniri A, Batooli H (2010) The bioactive and Volatile constituents of Prangos acaulis (DC) bornm extracted using hydrodistillation and nano 
scale injection techniques. Dig J Nanomater Biostruct 5:263-266

Mir FA (2015) Spectrophotometric and electrical properties of imperatorin: an organic molecule. Appl Phys A Mater Sci Process 120:1659-1663. https://doi.org/10.1007/s00339015-9384-9

Mir FA, Khan SH (2016) UV photoprotection of osthol. Radiat Eff Defects Solids 171:943-950. https://doi.org/10.1080/ 10420150.2016.1259240

Mirzaei HH, Ramezani Z (2008) Volatile components of the essential oil of Prangos asperula from West of Iran. Asian J Chem 20:3763-3766

Mneimne M, Baydoun S, Nemer N, Arnold A (2016) Chemical composition and antimicrobial activity of essential oils isolated from aerial parts of Prangos asperula Boiss. (Apiaceae) growing wild in Lebanon. Med Plant Res 5:5-9. https://doi.org/10.5376/mpr.2016.06.0003

Mohammadhosseini M (2012) Chemical profile and antibacterial activity in hydrodistilled oil from aerial parts of Prangos ferulacea (L.) Lindl. and prediction of gas chromatographic retention indices by using genetic algorithm multiple linear regressions. Asian J Chem 24:3814-3820

Mohammadhosseini M, Zamani HA, Akhlaghi H, Nekoei M (2011) Hydrodistilled volatile oil constituents of the aerial parts of Prangos serpentinica (Rech.f., Aell. Esfand.) Hernnstadt and Heyn from Iran and quantitative structureretention relationship simulation. J Essent Oil Bear Plants 14:559-573. https://doi.org/10.1080/0972060X.2011. 10643973

Mohebi Z (2017) The influence of plant growth satge, individuals of species, and extraction methods on the essential oil content and the chemical composition of Prangos ferulacea (L.) Lindl. Appl Ecol Environ Res 15:1765-1776. https://doi.org/10.15666/aeer/1504_17651776

Moradalizadeh M, Salajegheh M, Mehrabpanah M (2015) Chemical characterization of the essential oil of Prangos cheilanthifolia from Iran. Chem Nat Compd 51:573-574. https://doi.org/10.1007/s10600-015-1349-X

Mouri C, Mozaffarian V, Zhang X, Laursen R (2014) Characterization of flavonols in plants used for textile dyeing and the significance of flavonol conjugates. Dye Pigment 100:135-141. https://doi.org/10.1016/j.dyepig.2013.08. 025

Mullen M, Pathak M, West J et al (1984) Carcinogenic effects of monofunctional and bifunctional furocoumarins. Natl Cancer Inst Monogr 66:205-210

Namjoyan F, Azemi ME, Abdollahi E et al (2015) Angiotensin I converting enzyme inhibitory activities of hydroalcoholic extract of Nardostachys jatamansi, Prangos ferulacea and Marrubium vulgare. Jundishapur J Nat Pharm Prod 10:2

Nazemisalman B, Vahabi S, Yazdinejad A et al (2018) Comparison of antimicrobial effect of Ziziphora tenuior, Dracocephalum moldavica, Ferula gummosa, and Prangos ferulacea essential oil with chlorhexidine on Enterococcus faecalis: an in vitro study. Dent Res J (Isfahan) 15:111-116. https://doi.org/10.4103/1735-3327.92919

Nazemiyeh H, Razavi SM, Delazar A et al (2007a) Essential oil composition of the umbels and fruit of Prangos uloptera DC. Nat Prod Commun 2:89-91

Nazemiyeh H, Razavi SM, Hajiboland R et al (2007b) Composition of the essential oils of Prangos scabra fruits and inflorescence from Iran. Chem Nat Compd 43:736-737. https://doi.org/10.1007/s10600-007-0251-6

Newman DJ, Cragg GM (2012) Natural products as sources of new drugs over the 30 years from 1981 to 2010. J Nat Prod 75:311-335. https://doi.org/10.1021/np200906s

Nosrati M, Behbahani M (2016) In vitro and in silico antibacterial activity of Prangos ferulacea (L) Lindl and Prangos uloptera DC, and their mutagenicity in the Ames test. J Microbiol Biotechnol Food Sci 6:930-936. https://doi. org/10.15414/jmbfs.2016/17.6.3.930-936

Numonov S, Bobakulov K, Numonova M et al (2018) New coumarin from the roots of Prangos pabularia. Nat Prod Res 32:2325-2332. https://doi.org/10.1080/14786419. 2017.1413558

Oke Altuntas F, Aslim B, Duman H (2016) The anti-lipid peroxidative, metal chelating, and radical scavenging properties of the fruit extracts from endemic Prangos meliocarpoides boiss var. Meliocarpoides. Gazi Univ J Sci 29:537-542

OkeAltuntas F, Duman H, Aslim B (2011) Metal chelating, radical-scavenging and anti-lipid peroxidative activities of various extracts from two endemic species belonging to the genus Prangos Lindl (Umbelliferae). Planta Med 77:1282817. https://doi.org/10.1055/s-0031-1282817

Oke-Altuntas F, Aslim B, Duman H (2012) The inhibitory effects of Turkish endemic Prangos species against some food borne pathogens commonly found in milk and cheese. Planta Med 78:1321094. https://doi.org/10.1055/s-00321321094

Oke-Altuntas F, Aslim B, Duman H et al (2015) The relative contributions of chlorogenic acid and rutin to antioxidant activities of two endemic Prangos (Umbelliferae) species ( $P$. heynia and $P$. denticulata). J Food Biochem 39:409-416. https://doi.org/10.1111/jfbc.12137

Ozcan M (1999) Antifungal effects of Micromeria myrtifolia Boiss. \& Hohen. in Boiss. and Prangos uechtritzii Boiss. Hawsskn decoctions. Acta Aliment 28:355-360. https:// doi.org/10.1556/AAlim.28.1999.4.6

Ozcan M, Bagci Y, Akgul A et al (2000) Chemical composition of the essential oil of Prangos uechtritzii Boiss. et Hausskn. fruits from Turkey. J Essent Oil Res 12:183-185. https:// doi.org/10.1080/10412905.2000.9699493

Ozek G, Ozek T, Baser KHC et al (2006) Comparison of the essential oils of Prangos turcica A. Duran, M. Sagiroglu et $\mathrm{H}$. Duman fruits obtained by different isolation techniques. J Essent Oil Res 18:511-514

Özek G, Özek T, Işcan G et al (2007) Comparison of hydrodistillation and microdistillation methods for the analysis of fruit volatiles of Prangos pabularia Lindl., and evaluation of its antimicrobial activity. S Afr J Bot 73:563-569. https://doi.org/10.1016/j.sajb.2007.05.002

Ozek G, Bedir E, Tabanca N et al (2018) Isolation of eudesmane type sesquiterpene ketone from Prangos heyniae $\mathrm{H}$. Duman \& MFWatson essential oil and mosquitocidal activity of the essential oils. OPEN Chem 16:453-467. https://doi.org/10.1515/chem-2018-0051

Ranjbar S, Shokoohinia Y, Ghobadi S et al (2013) Studies of the interaction between isoimperatorin and human serum albumin by multispectroscopic method: identification of possible binding site of the compound using esterase 
activity of the protein. Sci World J. https://doi.org/10.1155/ 2013/305081

Razavi SM (2012a) Chemical composition and some allelopathic aspects of essential oils of (Prangos ferulacea L.) Lindl at different stages of growth. J Agric Sci Technol 14:349-356

Razavi SM (2012b) Chemical and allelopathic analyses of essential oils of Prangos pabularia Lindl. from Iran. Nat Prod Res 26:2148-2151. https://doi.org/10.1080/ 14786419.2011.633079

Razavi SM, Nejad-Ebrahimi S (2011) Volatile constituent distribution of Prangos coryombosa Boiss at two stages of growth. Nat Prod Res 25:627-633. https://doi.org/10.1080/ 14786419.2010.488626

Razavi SM, Nazemiyeh H, Delazar A et al (2008a) Coumarins from the roots of Prangos uloptera. Phytochem Lett 1:159-162. https://doi.org/10.1016/j.phytol.2008.07.009

Razavi SM, Nazemiyeh H, Hajiboland R et al (2008b) Coumarins from the aerial parts of Prangos uloptera (Apiaceae). Rev Bras Farmacogn 18:1-5. https://doi.org/10. 1590/S0102-695X2008000100002

Razavi SM, Zahri S, Nazemiyeh H et al (2009a) A furanocoumarin from Prangos uloptera roots, biological effects. Nat Prod Res 23:1522-1527. https://doi.org/10. 1080/14786410802691909

Razavi SM, Zahri S, Zarrini G et al (2009b) Biological activity of quercetin-3-O-glucoside, a known plant flavonoid. Russ J Bioorgan Chem 35:376-378. https://doi.org/10.1134/ S1068162009030133

Razavi SM, Nazemiyeh H, Zarrini G et al (2010a) Chemical composition and antimicrobial activity of essential oil of Prangos ferulaceae (L.) Lindl from Iran. Nat Prod Res 24:530-533. https://doi.org/10.1080/14786410802379539

Razavi SM, Zahri S, Motamed Z, Ghasemi G (2010b) Bioscreening of oxypeucedanin, a known furanocoumarin. Iran J Basic Med Sci 13:133-138

Razavi SM, Zarrini G, Zahri S, Mohammadi S (2010c) Biological activity of Prangos uloptera DC. roots, a medicinal plant from Iran. Nat Prod Res 24:797-803. https://doi.org/ 10.1080/14786410802588667

Razavi SM, Nazemiyeh H, Delazar A et al (2011a) Chemical variation of the essential oil of Prangos uloptera DC. at different stages of growth. Nat Prod Res 25:663-668. https://doi.org/10.1080/14786410802270811

Razavi SM, Zarrini G, Rad FG (2011b) Isoarnottinin 4'-glucoside, a glycosylated coumarin from Prangos uloptera, with biological activity. Russ J Bioorgan Chem 37:240-243. https://doi.org/10.1134/S1068162011020130

Ribeiro CVC, Kaplan MAC (2002) Tendências evolutivas de famílias produtoras de cumarinas em angiospermae. Quim Nova 25:533-538. https://doi.org/10.1590/S010040422002000400004

Rostami S, Aslim B, Duman H (2012) In vitro anti-inflammatory and anti-proliferatIve effects of Prangos platychloena Boiss.ex Tchih on colorectal cancer cell line. Planta Med. https://doi.org/10.1055/s-0032-1320990

Rustaiyan A, Mazloomifar H, Masoudi S, Aghjani Z (2006) Volatile oils of Ducrosia assadii Alava. and Prangos acaulis (DC.) Bornm. from Iran. J Essent Oil Res 18:682-684. https://doi.org/10.1080/10412905.2006. 9699205
Saab AM, Lampronti I, Finotti A et al (2012) In vitro evaluation of the biological activity of Lebanese medicinal plants extracts against herpes simplex virus type 1. Minerva Biotecnol 24:117-121

Sadeghi H, Bazdar M (2018) Effects of Prangos ferulacea aqueous and hydroalcoholic extracts obtained from different organs on the regeneration of Trifolium resupinatum. Acta Physiol Plant. https://doi.org/10.1007/s11738-0182626-7

Sagun E, Durmaz H, Tarakci Z, Sagdic O (2006) Antibacterial activities of the extracts of some herbs used in Turkish herby cheese against listeria monocytogenes serovars. Int J Food Prop 9:255-260. https://doi.org/10.1080/ 10942910600596365

Sajjadi SE, Eskandarian A-A, Shokoohinia Y et al (2016) Antileishmanial activity of prenylated coumarins isolated from Ferulago angulata and Prangos asperula. Res Pharm Sci 11:324-331. https://doi.org/10.4103/1735-5362.189314

Salehi S, Zahri S, Razavi SM (2016) Cytotoxic effect of Prangos Pabularia extract on HELA cell line a medicinal plant. Int J Med Res Heal Sci 5:547-552

Sarma AD, Mallick AR, Ghosh AK (2010) Free radicals and their role in different clinical conditions: an overview. Int J Pharm Sci Res 1:185-192

Sefidkon F, Navaii MN (2001) Chemical composition of the oil of Prangos uloptera DC. J Essent Oil Res 13:84-85. https://doi.org/10.1080/10412905.2001.9699620

Seidi Damyeh M, Niakousari M (2016) Impact of ohmic-assisted hydrodistillation on kinetics data, physicochemical and biological properties of Prangos ferulacea Lindle. essential oil: comparison with conventional hydrodistillation. Innov Food Sci Emerg Technol 33:387-396. https:// doi.org/10.1016/j.ifset.2015.12.009

Serkerov SV, Kagramanov AA, Abbasov RM, Aliev AM (1976) Coumarins of Prangos latiloba. Chem Nat Compd 12(1):83

Shagova LI, Pimenov MG, Kuznetsova GA (1976) Coumarins from the roots of Prangos quasiperforata. Chem Nat Compd 12:336. https://doi.org/10.1007/BF00567813

Shikishima Y, Takaishi Y, Honda G et al (2001a) Terpenoids and gamma-pyrone derivatives from Prangos tschimganica. Phytochemistry 57:135-141. https://doi.org/10.1016/ S0031-9422(00)00407-6

Shikishima Y, Takaishi Y, Honda G et al (2001b) Chemical constituents of Prangos tschimganica; structure elucidation and absolute configuration of coumarin and furanocoumarin derivatives with anti-HIV activity. Chem Pharm Bull (Tokyo) 49:877-880. https://doi.org/10.1248/ cpb.49.877

Shokoohinia Y, Sajjadi S-E, Gholamzadeh S et al (2014) Antiviral and cytotoxic evaluation of coumarins from Prangos ferulacea. Pharm Biol 52:1543-1549. https://doi. org/10.3109/13880209.2014.907322

Stevens PF (2001) Angiosperm phylogeny website. Version 14 Sumer Ercan F, Bas H, Koc M et al (2013) Insecticidal activity of essential oil of Prangos ferulacea (Umbelliferae) against Ephestia kuehniella (Lepidoptera: Pyralidae) and Trichogramma embryophagum (Hymenoptera: Trichogrammatidae). Turk J Agric For 37:719-725. https:// doi.org/10.3906/tar-1211-15 
Tabanca N, Tsikolia M, Ozek G et al (2016) The identification of suberosin from prangos pabularia essential oil and its mosquito activity against aedes aegypti. Rec Nat Prod 10:311-325

Tabanca N, Wedge DE, Li X-C et al (2018) Biological evaluation, overpressured layer chromatography separation, and isolation of a new acetylenic derivative compound from Prangos platychlaena ssp. platychlaena fruit essential oils. JPC J Planar Chromatogr TLC 31:61-71. https://doi.org/ 10.1556/1006.2018.31.1.8

Tada Y, Shikishima Y, Takaishi Y et al (2002) Coumarins and $\gamma$ pyrone derivatives from Prangos pabularia: antibacterial activity and inhibition of cytokine release. Phytochemistry 59:649-654. https://doi.org/10.1016/S00319422(02)00023-7

Tan N, Yazici-Tutunis S, Bilgin M et al (2017) Antibacterial activities of pyrenylated coumarins from the roots of Prangos hulusii. Molecules. https://doi.org/10.3390/ molecules22071098

Tütüniş Yazıcı S, Tan N, Meriçli F et al (2013) Biological activities of endemic Prangos hulusii. Planta Med. https:// doi.org/10.1055/s-0033-1352455

Ulubelen A, Topcu G, Tan N et al (1995) Biological activities of a Turkish medicinal plant, Prangos platychlaena.
J Ethnopharmacol 45:193-197. https://doi.org/10.1016/ 0378-8741(94)01215-L

Uzel A, Dirmenci T, Celik A, Arabaci T (2006) Composition and antimicrobial activity of Prangos platychlaena and P-uechtritzii. Chem Nat Compd 42:169-171. https://doi. org/10.1007/s10600-006-0069-7

Yazici TS, Tan N, Mericli F et al (2013) Biological activities of endemic Prangos hulusii. Planta Med 79:1275

Yoon HS, Moon SC, Kim ND et al (2000) Genistein induces apoptosis of RPE-J cells by opening mitochondrial PTP. Biochem Biophys Res Commun 276:151-156

Yousefi K, Hamedeyazdan S, Hodaei D et al (2017) An in vitro ethnopharmacological study on Prangos ferulacea: a wound healing agent. Bioimpacts 7:75-82. https://doi.org/ 10.15171/bi.2017.10

Zahri S, Razavi SM, Moatamed Z (2012) Antioxidant activity and cytotoxic effect of aviprin and aviprin- $3^{\prime \prime}-\mathrm{O}-\mathrm{D}$-glucopyranoside on LNCaP and HeLa cell lines. Nat Prod Res 26:540-547. https://doi.org/10.1080/14786419.2010. 529442

Publisher's Note Springer Nature remains neutral with regard to jurisdictional claims in published maps and institutional affiliations. 